University of South Florida

DIGITAL COMMONS

Digital Commons @ University of

@ UNIVERSITY OF SOUTH FLORIDA

South Florida

\title{
Analysis of the Florida Department of Transportation Transit Corridor Program/Projects: Technical Memorandum \#1 - Review and Summary of Transit Corridor Plans
}

CUTR

Follow this and additional works at: https://digitalcommons.usf.edu/cutr_nctr

\section{Scholar Commons Citation}

CUTR, "Analysis of the Florida Department of Transportation Transit Corridor Program/Projects: Technical Memorandum \#1 - Review and Summary of Transit Corridor Plans" (2000). Research Reports. 1.

https://digitalcommons.usf.edu/cutr_nctr/1

This Technical Report is brought to you for free and open access by the National Center for Transit Research (NCTR) Archive (2000-2020) at Digital Commons @ University of South Florida. It has been accepted for inclusion in Research Reports by an authorized administrator of Digital Commons @ University of South Florida. For more information, please contact digitalcommons@usf.edu. 


\title{
ANALYSIS OF FLORIDA DEPARTMENT OF TRANSPORTATION TRANSIT CORRIDOR PROGRAM/PROJECTS
}

\author{
Technical Memorandum Number One
}

Review and Summary of Transit Corridor Plans

\author{
Prepared for \\ Florida Department of Transportation
}

Prepared by

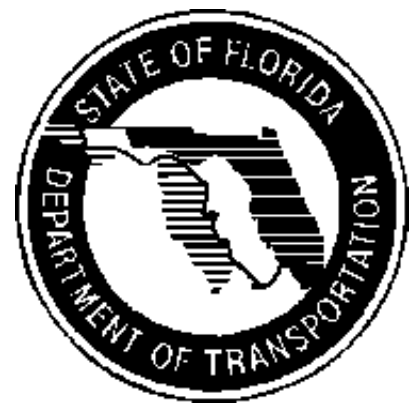

Center for Urban Transportation Research

College of Engineering University of South Florida

Tampa, Florida

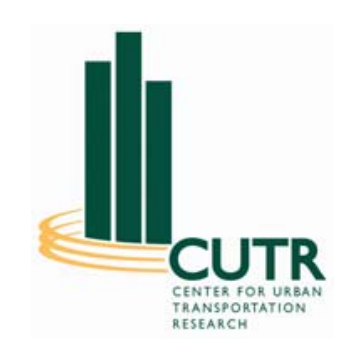

May 2000

REVIEW AND SUMMARY OF TRANSIT CORRIDOR PROJECTS 


\section{TABLE OF CONTENTS}

SECTION

PAGE

PURPOSE

TRANSIT CORRIDOR PROGRAM

FDOT DISTRICT OFFICES

PROJECT SUMMARIES $\ldots \ldots \ldots \ldots \ldots \ldots \ldots \ldots \ldots \ldots \ldots \ldots$

Summary of Funded Projects $\ldots \ldots \ldots \ldots \ldots \ldots \ldots \ldots \ldots \ldots \ldots$

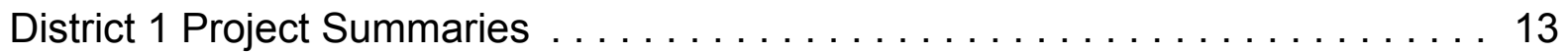

District 2 Project Summaries $\ldots \ldots \ldots \ldots \ldots \ldots \ldots \ldots \ldots \ldots \ldots \ldots \ldots \ldots \ldots \ldots \ldots \ldots$

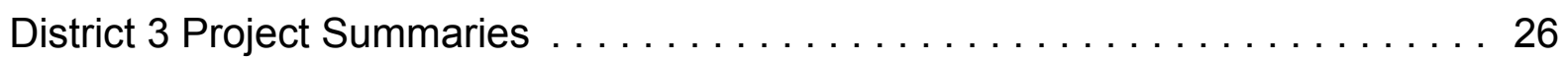

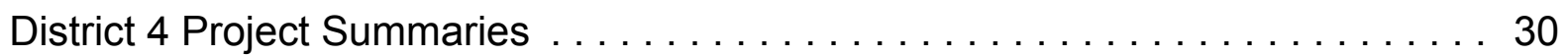

District 5 Project Summaries $\ldots \ldots \ldots \ldots \ldots \ldots \ldots \ldots \ldots \ldots \ldots \ldots \ldots \ldots \ldots \ldots \ldots$

District 6 Project Summaries . . . . . . . . . . . . . . . . 34

District 7 Project Summaries $\ldots \ldots \ldots \ldots \ldots \ldots \ldots \ldots \ldots \ldots \ldots \ldots \ldots \ldots \ldots \ldots \ldots \ldots$

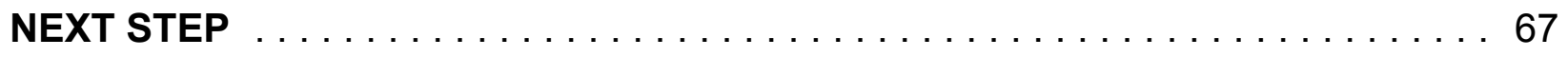




\section{Review and Summary of Existing Transit Corridor Projects}

\section{PURPOSE}

The purpose of this project is to undertake a consolidated, comprehensive review of the Florida Department of Transportation Transit Corridor Program. The project team will review all transit corridor projects completed on or after July 1, 1993. Specific tasks associated with this effort will be the review of the project scopes defined in the joint participation agreements (JPAs) between the district offices and the various recipients; the identification of the goals and objectives of each of the projects and the milestones established as a measure of the progress in meeting and/or exceeding those established goals and objectives; and quarterly and final reports submitted by the grantee for the project.

Based on the information obtained through this effort, CUTR will seek to establish the relative success of each project in meeting the goals and objectives established and the overall statewide goal of the program to relieve congestion and improve system capacity along designated corridors. Along with this exercise, CUTR will also identify those areas that have demonstrated significant local commitment to ensuring the success of the project. Finally, the lessons learned from the implementation of these projects will be shared with other transit systems within the State of Florida.

In an effort to assist the Department in streamlining and/or improving current procedures and policies, during this review and subsequent discussions with FDOT staff, CUTR will review the overall Transit Corridor Program process. Recommendations for procedural changes are contained in Technical Memorandum Three.

Consistent with Task 1 of this project CUTR has summarized all the project descriptions from the Joint Participation Agreements for the Transit Corridor Program executed from July 1, 1993 through December 31, 1999 and for those projects which began prior to July of 1993 but have continued into the review period through supplemental agreements. Recently implemented projects have been summarized in lesser detail using the scope contained in the JPA and any available progress reports. Where critical reporting/data was lacking, CUTR interviewed FDOT and transit agency personnel in an attempt to gather the required information. As necessary, site visits were made to the 
FDOT district offices and/or transit agencies (or other grantees) in order to interview personnel and observe project accomplishments.

Task 2 builds on Task 1 with the emphasis on identifying the success and failure of Transit Corridor projects. This information is provided in Technical Memorandum Two entitled "Summary of Transit Corridor Projects Strengths and Weaknesses." It is intended that the results of this analysis may also be presented at the Florida Transit Association's annual or mid-year conferences.

Finally, in Task 3 CUTR interviewed involved FDOT personnel at both the Central Office and District Offices to discuss the strengths and weaknesses of the overall Transit Corridor Program. CUTR also studied the FDOT Transit Corridor Procedure, Topic Number 725-030-003-d, reviewing the sections developed for program management and implementation; funding and eligible costs; capital acquisition and management; and project implementation and monitoring. From these efforts recommendations have been provided in Technical Memorandum Three to improve the Transit Corridor Procedure and related processes.

\section{TRANSIT CORRIDOR PROGRAM}

Section 341.051, Florida Statutes defines the authority of the FDOT for funding transit corridor projects. The FDOT Transit Corridor Program was enacted by the Florida Legislature to provide funding to public agencies to undertake projects "... to relieve congestion and improve capacity within identified transportation corridors by increasing people-carrying capacity of the system through the use and facilitated movement of high-occupancy conveyances" (341.031(10), Florida Statutes). The Department is authorized to fund up to 100 percent of the capital and net operating costs of transit corridor projects (Section 341.051(5)(e), F.S.). The initial duration of these projects shall not exceed a period of two years unless the project is reauthorized by the legislature. Reauthorizations are based on a determination that the project has meet or is exceeding the goals and objectives established for the project.

Transit corridor projects must have clearly defined goals and objectives. Milestones must be developed by that will allow a measurement of progress toward achieving the goals and objectives. Goals, objectives, and milestones must be consistent with the local government comprehensive plan(s) of the affected jurisdiction(s), the strategic regional policy plan developed for the region, the MPO's long range transportation plan, and the Florida Transportation Plan and must be approved by the district FDOT office 
initiating the project. As mentioned previously, after the initial two-year period, projects consistently meeting milestones may be reauthorized through the Department's Work Program.

The FDOT Central Office annually reviews existing Transit corridor projects and allocates to the district offices sufficient funds to cover these ongoing projects. Priority for funding is given to those projects meeting the adopted goals and objectives. Any funds that remain are allocated to each of the district offices by a formula based on each district's percentage of the total urbanized population for the state. The district offices may program up to 100 percent of the cost for implementing the project.

Upon the approval of a project, a technical advisory group (TAG) is established with membership that may include but not be limited to representatives from the district's public transportation, planning, traffic engineering, and design offices; the MPO; city and/or county planning, traffic operations, and law enforcement offices; the local transit agency and transportation providers; regional commuter service program; transportation management organizations/associations; and FDOT Central Office. The TAG is chaired by the FDOT district office. This group is responsible for establishing the goals and objectives for the project; evaluating the project's successes and/or failures; and recommending future actions relative to the project.

District offices are required to review and, if necessary, assist in the development of, and approve transit corridor plans; select transit corridor projects for funding based on priorities established in consultation with the Central Office; select membership and chair the TAG; monitor and evaluate all transit corridor projects within their district; provide biennial reports to Central Office on the success and/or failure of each of the projects; manage contracts with each recipient; and provide technical assistance to grantees, as required.

\section{FDOT DISTRICT OFFICES}

There are currently seven FDOT District offices serving the 67 counties of Florida. Figure 1 shows the boundaries served by the District offices. Each district's Public Transportation Office is responsible for project management and implementation of the program at the local level. This includes the execution of the Joint Participation Agreements (JPAs) and any supplemental agreements that change the project's scope, 
expiration date, or budget; invoicing; monitoring of the project's progress; and other activities as discussed above. 
FIGURE 1

FLORIDA DEPARTMENT OF TRANSPORTATION DISTRICT BOUNDARIES

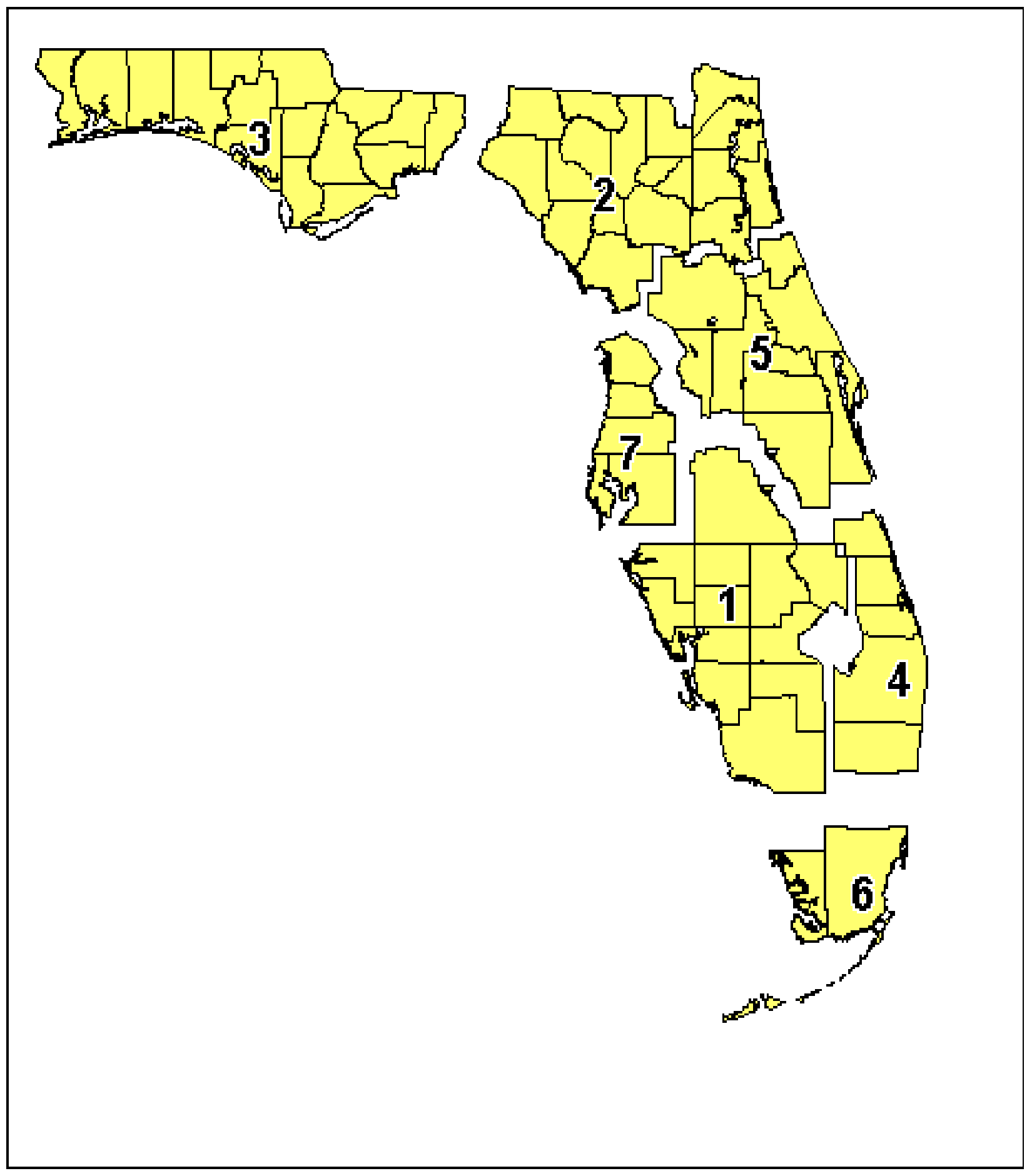


Table 1

Transit Corridor Program Participants By FDOT District

\begin{tabular}{|l|l|l|}
\hline $\begin{array}{l}\text { FDOT District/ } \\
\text { Public Transit Office Location }\end{array}$ & Public Transportation Agency Recipient & Other Recipient \\
\hline $\begin{array}{l}\text { 1 - Bartow/ } \\
\text { Ft. Myers }\end{array}$ & $\begin{array}{l}\text { Lee County Transit (LeeTran) } \\
\text { Sarasota County Area Transit (SCAT) } \\
\text { Manatee County Area Transit (MCAT) }\end{array}$ & \\
\hline $\mathbf{2}$ - Jacksonville & $\begin{array}{l}\text { Jacksonville Transportation Authority (JTA) } \\
\text { Gainesville Regional Transit System (RTS) }\end{array}$ & \\
\hline $\mathbf{3}$ - Chipley & Escambia County Area Transit (ECAT) & \\
\hline $\mathbf{4}$ - Ft Lauderdale & Broward County Mass Transit Division (BCT) & \\
\hline $\mathbf{5}$ - Orlando & $\begin{array}{l}\text { Central Florida Regional Transportation } \\
\text { Authority (LYNX) }\end{array}$ & \\
\hline $\mathbf{6}$ - Miami & Miami-Dade Transit Agency (MDTA) & City of Miami Beach \\
\hline $\mathbf{7}$ - Tampa & $\begin{array}{l}\text { Hillsborough Area Regional Transit Authority } \\
\text { (HART) } \\
\text { Pasco County Public Transportation Division } \\
\text { Pinellas Suncoast Transit Authority (PSTA) }\end{array}$ & \\
\hline
\end{tabular}




\section{PROJECT SUMMARIES}

\section{Summary of Funded Projects}

Between July 1, 1993 and December 31, 1999, funding for 27 transit corridor projects was awarded by the FDOT to local providers of public transportation services. The total FDOT transit corridor program funds allocated for these projects was $\$ 31,602,626$. This total includes projects that were initially started prior to July 1, 1993 that have been continued through subsequent or supplemental JPAs and project that were awarded prior to January 1, 2000 but are not yet under a JPA. Table 2 summarizes the projects funded by each of the seven FDOT districts. This table also shows the Work Program Identification (WPI) number or financial project number (FPN) used by the FDOT to identify JPAs by district, and provides the execution date of any supplemental agreements for the project, if applicable. Finally, the table shows the funds allocated by the FDOT, and whether written progress or final reports were completed for each project.

Based on the progress and final reports submitted by the recipients of the transit corridor funds, as well as interviews with FDOT staff and/or the recipients, summary project descriptions have been developed and are highlighted by district and by recipient in the following pages. 
SUMMARY OF FDOT TRANSIT CORRIDOR PROJECTS

Projects Awarded Between July 1, 1993 and December 31, 1999

\begin{tabular}{|c|c|c|c|c|c|c|}
\hline $\begin{array}{l}\text { District \#/ } \\
\text { Agency Name/ } \\
\text { Project Name }\end{array}$ & WPI/FPN\# & $\begin{array}{l}\text { SJPA } \\
\text { (N or } \\
\text { Date(s)) }\end{array}$ & $\begin{array}{c}\text { JPA } \\
\text { Execution } \\
\text { Date }\end{array}$ & $\begin{array}{l}\text { FDOT Funds } \\
\text { Allocated }\end{array}$ & $\begin{array}{l}\text { Progress } \\
\text { Reports } \\
\text { (Y or N) }\end{array}$ & $\begin{array}{c}\text { Final } \\
\text { Report } \\
(\mathrm{Y}, \mathrm{N} \text { or } \mathrm{N} / \mathrm{A})\end{array}$ \\
\hline \multicolumn{7}{|l|}{ District 1} \\
\hline \multicolumn{7}{|l|}{ LeeTran } \\
\hline U.S. 41 Corridor Project & \#1814972 & $12 / 98$ & $4 / 24 / 96$ & $\$ 8,264,881$ & Y & $N / A$ \\
\hline \multicolumn{7}{|l|}{ Sarasota County Area Transit } \\
\hline U.S. 41 (S. Tamiami Trail) Corridor Project & \#4071071 & $\mathrm{N} / \mathrm{A}$ & $\mathrm{N} / \mathrm{A}$ & $\$ 267,000$ & $\mathrm{~N} / \mathrm{A}$ & $\mathrm{N} / \mathrm{A}$ \\
\hline \multicolumn{7}{|l|}{ Manatee County Area Transit } \\
\hline Manatee Avenue/S.R. 64 Corridor Project & $\# 4071171$ & $\mathrm{~N} / \mathrm{A}$ & $3 / 30 / 00$ & $\$ 261,000$ & $\mathrm{~N} / \mathrm{A}$ & $\mathrm{N} / \mathrm{A}$ \\
\hline \multicolumn{7}{|l|}{ District 2} \\
\hline \multicolumn{7}{|l|}{ Jacksonville Transportation Authority (JTA) } \\
\hline Park-N-Ride Commuter Express Routes & \#2814311 & $12 / 97 ; 12 / 99$ & $12 / 22 / 95$ & $\$ 109,000$ & Y & $\mathrm{N} / \mathrm{A}$ \\
\hline \multicolumn{7}{|l|}{ Gainesville Regional Transit System (RTS) } \\
\hline SW Gainesville Enhanced Bus Service & \#2810791 & $\begin{array}{l}6 / 98 \\
6 / 99\end{array}$ & $12 / 18 / 97$ & $\$ 248,335$ & Y & $N / A$ \\
\hline Night Bus Service & \#2810829 & $\mathrm{N}$ & $9 / 2 / 98$ & $\$ 140,000$ & Y & $N / A$ \\
\hline Tower Road Corridor Service & \#2810830 & $\mathrm{N}$ & $12 / 31 / 98$ & $\$ 83,000$ & $\mathrm{Y}$ & N/A \\
\hline
\end{tabular}




\section{SUMMARY OF FDOT TRANSIT CORRIDOR PROJECTS}

Projects Awarded Between July 1, 1993 and December 31, 1999

\begin{tabular}{|c|c|c|c|c|c|c|}
\hline $\begin{array}{l}\text { District \#l } \\
\text { Agency Name/ } \\
\text { Project Name }\end{array}$ & WPI/FPN\# & $\begin{array}{l}\text { SJPA } \\
\text { (N or } \\
\text { Date(s)) }\end{array}$ & $\begin{array}{c}\text { JPA } \\
\text { Execution } \\
\text { Date } \\
\end{array}$ & $\begin{array}{l}\text { FDOT Funds } \\
\text { Allocated }\end{array}$ & $\begin{array}{c}\text { Progress } \\
\text { Reports } \\
(\mathrm{Y} \text { or } \mathrm{N})\end{array}$ & $\begin{array}{c}\text { Final } \\
\text { Report } \\
(\mathrm{Y}, \mathrm{N} \text { or } \mathrm{N} / \mathrm{A})\end{array}$ \\
\hline \multicolumn{7}{|l|}{ District 3} \\
\hline \multicolumn{7}{|l|}{ Escambia County Area Transit (ECAT) } \\
\hline Davis Highway Corridor Project & \#2258251 & $\mathrm{N}$ & $1 / 97$ & $\$ 873,962$ & $\mathrm{Y}$ & $\mathrm{N} / \mathrm{A}$ \\
\hline Blue Angel Highway Corridor & $\# 2258341$ & $\mathrm{~N}$ & $12 / 97$ & $\$ 468,500$ & $\mathrm{Y}$ & $\mathrm{N} / \mathrm{A}$ \\
\hline \multicolumn{7}{|l|}{ District 4} \\
\hline \multicolumn{7}{|l|}{ Broward County Transit (BCT) } \\
\hline Southwest Broward Express & $\# 4811331$ & $7 / 96 ; 4 / 99$ & $6 / 94$ & $\$ 1,125,000$ & $Y$ & $\mathrm{~N} / \mathrm{A}$ \\
\hline \multicolumn{7}{|l|}{ District 5} \\
\hline \multicolumn{7}{|l|}{$\begin{array}{l}\text { Central Florida Regional Transportation } \\
\text { Authority (CFRTA), d.b.a. LYNX }\end{array}$} \\
\hline I-4 Express Survey & $\# 5815144$ & $\mathrm{~N}$ & $3 / 95$ & $\$ 10,000$ & $\mathrm{Y}$ & $\mathrm{Y}$ \\
\hline \multicolumn{7}{|l|}{ District 6} \\
\hline \multicolumn{7}{|l|}{ Metro-Dade Transit Agency } \\
\hline Northwest $27^{\text {th }}$ Avenue MAX & \#6819003 & $\begin{array}{c}6 / 91 ; 6 / 94 \\
10 / 95\end{array}$ & $6 / 26 / 87$ & $\$ 1,216,000$ & Y & Y \\
\hline
\end{tabular}


SUMMARY OF FDOT TRANSIT CORRIDOR PROJECTS

Projects Awarded Between July 1, 1993 and December 31, 1999

\begin{tabular}{|c|c|c|c|c|c|c|}
\hline $\begin{array}{l}\text { District \#l } \\
\text { Agency Name/ } \\
\text { Project Name }\end{array}$ & WPI/FPN\# & $\begin{array}{l}\text { SJPA } \\
\text { (N or } \\
\text { Date(s)) }\end{array}$ & $\begin{array}{c}\text { JPA } \\
\text { Execution } \\
\text { Date }\end{array}$ & $\begin{array}{l}\text { FDOT Funds } \\
\text { Allocated }\end{array}$ & $\begin{array}{c}\text { Progress } \\
\text { Reports } \\
(\mathrm{Y} \text { or } \mathrm{N})\end{array}$ & $\begin{array}{c}\text { Final } \\
\text { Report } \\
(\mathrm{Y}, \mathrm{N} \text { or N/A) } \\
\end{array}$ \\
\hline Flagler MAX & $\begin{array}{l}\# 6810184 / \\
\# 6810237\end{array}$ & $\begin{array}{c}6 / 93 ; 6 / 94 \\
10 / 95 ; 6 / 96 \\
6 / 97 ; 12 / 97 \\
1 / 99 ; 12 / 99 \\
10 / 95\end{array}$ & $11 / 14 / 91$ & $\$ 6,722,172$ & $\mathrm{Y}$ & $\mathrm{N} / \mathrm{A}$ \\
\hline South Dade Busway & 6810309 & $\begin{array}{c}12 / 97 ; 1 / 99 \\
12 / 99\end{array}$ & $2 / 3 / 97$ & $\$ 2,996,976$ & $\mathrm{Y}$ & $\mathrm{N} / \mathrm{A}$ \\
\hline \multicolumn{7}{|l|}{ City of Miami Beach } \\
\hline Miami Beach Electric Shuttle & 6810341 & $\begin{array}{c}10 / 96 ; 11 / 98 \\
2 / 00 \\
\end{array}$ & $6 / 20 / 96$ & $\$ 650,000$ & Y & $N / A$ \\
\hline \multicolumn{7}{|l|}{ District 7} \\
\hline \multicolumn{7}{|l|}{$\begin{array}{l}\text { Hillsborough Area Regional Transit } \\
\text { Authority (HART) }\end{array}$} \\
\hline $\begin{array}{l}\text { Express Bus Service from Downtown } \\
\text { Tampa to Clearwater (200X) }\end{array}$ & 7813923 & $\begin{array}{c}6 / 88 ; 11 / 88 \\
8 / 90 ; 4 / 91 \\
8 / 91 ; 5 / 92 \\
12 / 94\end{array}$ & $10 / 26 / 95$ & $\$ 2,270,000$ & $\mathrm{Y}$ & $\mathrm{N} / \mathrm{A}$ \\
\hline
\end{tabular}


SUMMARY OF FDOT TRANSIT CORRIDOR PROJECTS

Projects Awarded Between July 1, 1993 and December 31, 1999

\begin{tabular}{|c|c|c|c|c|c|c|}
\hline $\begin{array}{l}\text { District \#l } \\
\text { Agency Namel } \\
\text { Project Name }\end{array}$ & WPI/FPN\# & $\begin{array}{l}\text { SJPA } \\
\text { (N or } \\
\text { Date(s)) }\end{array}$ & $\begin{array}{l}\text { JPA } \\
\text { Execution } \\
\text { Date }\end{array}$ & $\begin{array}{l}\text { FDOT Funds } \\
\text { Allocated }\end{array}$ & $\begin{array}{l}\text { Progress } \\
\text { Reports } \\
\text { (Y or N) }\end{array}$ & $\begin{array}{c}\text { Final } \\
\text { Report } \\
(\mathrm{Y}, \mathrm{N} \text { or N/A) }\end{array}$ \\
\hline $\begin{array}{l}\text { Express Bus Service from Downtown } \\
\text { Tampa to Clearwater Mall (Continuation of } \\
\text { 200X - WPI \#7813923) }\end{array}$ & 7814028 & $4 / 97$ & $5 / 28 / 96$ & $\$ 500,000$ & Y & $\mathrm{N} / \mathrm{A}$ \\
\hline U.S. 41 Corridor Improvement Program & $\begin{array}{l}7810010 / \text { and } \\
7814115\end{array}$ & $11 / 99$ & $\begin{array}{l}3 / 24 / 92 \\
9 / 30 / 98\end{array}$ & $\$ 2,144,493$ & $\mathrm{Y}$ & $\mathrm{N} / \mathrm{A}$ \\
\hline $\begin{array}{l}\text { Express Bus Service from Net Park Transit } \\
\text { Center to Oldsmar }\end{array}$ & 4064791 & $\mathrm{~N}$ & $11 / 22 / 99$ & $\$ 125,000$ & N/A & $\mathrm{N} / \mathrm{A}$ \\
\hline \multicolumn{7}{|l|}{ Pinellas Suncoast Transit Authority (PSTA) } \\
\hline $\begin{array}{l}\text { Ulmerton Road Corridor - Route } 59 \\
\text { (Supplemental JPA extended Route 73) }\end{array}$ & 7816678 & $12 / 96 ; 7 / 97$ & $11 / 21 / 95$ & $\$ 1,100,000$ & $\mathrm{Y}$ & N/A \\
\hline Route $100 \mathrm{X}$ & 7816679 & $\begin{array}{c}9 / 95 ; 9 / 95 \\
7 / 97 ; 9 / 98 \\
11 / 99\end{array}$ & $6 / 1 / 95$ & $\$ 1,149,265$ & Y & $\mathrm{N} / \mathrm{A}$ \\
\hline $\begin{array}{l}\text { Alternate US } 19 \text { and SR } 686 \text { Corridors } \\
\text { Route \#98 Express Service }\end{array}$ & 4039011 & $9 / 99$ & $9 / 24 / 98$ & $\$ 225,712$ & $\mathrm{~N}$ & $N / A$ \\
\hline $\begin{array}{l}\text { Ulmerton Road (SR 688) Corridor Route } \\
\text { \#99 Express Service }\end{array}$ & 4039031 & $9 / 99$ & $9 / 24 / 98$ & $\$ 232,690$ & $\mathrm{Y}$ & $\mathrm{N} / \mathrm{A}$ \\
\hline US 19 Corridor Service Marketing & 4064761 & $\mathrm{~N}$ & $8 / 18 / 99$ & $\$ 25,000$ & $\mathrm{~N}$ & N/A \\
\hline
\end{tabular}




\section{SUMMARY OF FDOT TRANSIT CORRIDOR PROJECTS}

Projects Awarded Between July 1, 1993 and December 31, 1999

\begin{tabular}{|c|c|c|c|c|c|c|}
\hline $\begin{array}{l}\text { District \#l } \\
\text { Agency Name/ } \\
\text { Project Name }\end{array}$ & WPI/FPN\# & $\begin{array}{l}\text { SJPA } \\
\text { (N or } \\
\text { Date(s)) }\end{array}$ & $\begin{array}{c}\text { JPA } \\
\text { Execution } \\
\text { Date }\end{array}$ & $\begin{array}{l}\text { FDOT Funds } \\
\text { Allocated }\end{array}$ & $\begin{array}{c}\text { Progress } \\
\text { Reports } \\
\text { (Y or N) }\end{array}$ & $\begin{array}{c}\text { Final } \\
\text { Report } \\
(\mathrm{Y}, \mathrm{N} \text { or } \mathrm{N} / \mathrm{A})\end{array}$ \\
\hline $\begin{array}{l}\text { Cross-County Service CR } 296 \text { Corridor } \\
\text { Route } 58\end{array}$ & 4064771 & $\mathrm{~N}$ & 9/28/99 & $\$ 80,708$ & $\mathrm{~N}$ & $\mathrm{~N} / \mathrm{A}$ \\
\hline $\begin{array}{l}\text { Fixed Route Service from Tarpon Mall to } \\
\text { Oldsmar (SR } 584 \text { Corridor) }\end{array}$ & 4064781 & $\mathrm{~N}$ & $11 / 9 / 99$ & $\$ 28,076$ & $\mathrm{~N}$ & N/A \\
\hline \multicolumn{7}{|l|}{ Pasco County Public Transportation } \\
\hline US 19 Corridor Project & 4064811 & $\mathrm{~N}$ & $10 / 28 / 99$ & $\$ 285,856$ & $\mathrm{~N}$ & $\mathrm{~N} / \mathrm{A}$ \\
\hline \multicolumn{4}{|l|}{ TOTAL FDOT CORRIDOR FUNDS } & \multicolumn{3}{|l|}{$\$ 31,602,626$} \\
\hline
\end{tabular}




\section{District 1 Project Summaries}

During the project time period from July 1, 1993 through December 31,1999 the FDOT District 1 Office awarded $\$ 8,264,881$ in Transit Corridor funding to LeeTran, $\$ 267,000$ to Sarasota County Area Transit (SCAT) and $\$ 261,000$ to Manatee County Area Transit (MCAT). The SCAT and MCAT projects have been awarded, however, JPAs were not in place on December 31, 1999. The project summaries are as follows:

\section{LeeTran}

Lee County Transit (LeeTran) is an independent division of the Lee County Government, and is governed by the Lee County Board of County Commissioners. LeeTran operates fixed-route motorbus service and contracts the demand response (ADA) service.

\section{US 41 Transit Corridor Project - WPI \#1814972}

\section{Project Scope}

This is a transit corridor project selected based on Lee County's transit corridor proposal which was approved by the Lee County Metropolitan Planning Organization on September 22, 1995. The project originally included the acquisition of buses, fareboxes and related equipment for use along the US 41corridor; promotion and marketing of services; and operating assistance.

The joint participation agreement, in the amount of $\$ 8,264,881$ (100\% state funds), between Lee Tran and the Department provided for the purchase of nine (9) full size, accessible, heavy duty, diesel powered transit coaches, nine (9) fareboxes and related equipment. The nine buses were to be used exclusively in the corridor. A minimum of three (3) information kiosks, 40 information signs, and eight park-n-ride signs were to be purchased by Lee Tran. In addition, a minimum of four (4) shelters were to be purchased and installed by Lee Tran. Total estimated capital costs provided in the project budget was $\$ 2,227,850$. The balance of the total project cost (an estimated $\$ 5,711,031$ ) was, and continues to be used to fund 100 percent of the operating deficit and for marketing (an estimated $\$ 326,000$ ). This is a five year project that commenced on April 24, 1996 (actual service start date 5/1/97) and will continue through State Fiscal Year 2000/2001. 


\section{Project Milestones/Goals}

The following annual ridership goals were initially established for the program:

\begin{tabular}{|c|c|c|c|}
\hline & $\underline{\text { Ridership }}$ & Annual \% Change & \% Cha \\
\hline Prior to Project Start & 251,588 & ------- & ------- \\
\hline End of First Year & 280,481 & $11.4 \%$ & $11.4 \%$ \\
\hline End of Second Year & 327,228 & $16.7 \%$ & $30.0 \%$ \\
\hline End of Third Year & 373,975 & $14.2 \%$ & $48.6 \%$ \\
\hline End of Fourth Year & 420,722 & $12.5 \%$ & $67.2 \%$ \\
\hline
\end{tabular}

Service Description

On May 1, 1997, service was implemented along the US 41 corridor. The hours of service at that time were 5:25 a.m. to 8:05 p.m., Monday through Saturday. Seven buses were placed in service with two additional buses available as spares. The 18.2 mile route followed US 41 from SR 78 (Pine Island Road) south to Sanibel Boulevard and returned with 20 minute headways. The route made appropriate connections and transfers with other Lee Tran buses in the system and with park-n-ride lots on both ends of the corridor and along the route. In December 1998, the JPA was modified extending the hours of operation to 10:00 p.m. and temporarily placed an additional vehicle in service for a total of eight, with one spare. The additional bus was needed to meet headways during road construction along the route. Project goals were changed with the extension of operating hours as follows:

$\begin{array}{lll}\mathbf{1}^{\text {st }} \text { Year } & 280,481 & 0 \% \\ 2^{\text {nd }} \text { Year } & 346,380 & 19 \% \\ 3^{\text {rd }} \text { Year } & 433,879 & 20 \% \\ 4^{\text {th }} \text { Year } & 488,114 & 11 \%\end{array}$




\section{Progress}

Year One - At the close of the first year of operation, Lee Tran reported that the project had been very successful, exceeding all the goals that were established. Ridership was 51 percent higher than expected with 423,451 passenger trips and farebox revenues were 77 percent higher than original estimates. Operating expenses came in at 10.5 percent under budget even though an additional bus had to be used to maintain 20 minute headways.

Year Two - The second annual report noted continued success for the project. During this year, Lee Tran added an additional 1 hour and 40 minutes of service in the evening providing service until 10:00 p.m. The expansion of service hours resulted in a ridership increase during December 1998 of 18 percent over that of December 1997. The annual ridership goal established for the second year of service was 346,380 passengers. Lee Tran surpassed this goal providing service to 493,988 passengers, 42.61 percent more than the established goal. The annual farebox goal for year two was $\$ 152,407$. Lee Tran collected $\$ 259,021$ in passenger fares, 69.95 percent higher than the established goal.

Year Three - In February 2000, Lee Tran submitted the third quarterly report for the third year of operation. As provided in that report, the project ridership, farebox revenue, and operating expense statistics demonstrates that the project is exceeding the goals established for year 3 . During the third quarter, there were 167,277 passenger trips and $\$ 82,329$ collected in farebox revenues for the Monday through Saturday service. Comparing the third quarters of the $2^{\text {nd }}$ and $3^{\text {rd }}$ year of operation, for the prior year there were 124,759 passenger trips, representing a third year increase of over 30 percent. The farebox revenue for the quarter $(\$ 82,329)$ represents an increase of over 25 percent from the same quarter in year 2 . Sunday service for the quarter carried 3,758 passengers and collected $\$ 2,477$ in farebox revenue. The measure of average passenger trips per day for Sunday during this quarter was 289 . When this service began, the average number of trips per day for Sunday was 150.

The marketing for the start-up of this project was exceptional. During the Winter of 1996, LeeTran partnered with 96K-Rock (a local radio station) to sponsor a "Magic Bus Design" contest. Nine division awards, one in each division, were made representing designs made by a person within a particular age group (i.e., under 7 years old; 7 - 13; 14 - 19; 20 - 29; 30 - 39; 40 - 49; 50 - 59; 60 - 69; and 70+ years of age). Each contestant was required to design one side of a Lee Tran bus (designs were placed on 
both sides of each bus; and each individual winners name and sponsor logos were placed on the rear of the bus). The contest was extremely successful. An unveiling of the buses was held on Friday, April 25, 1997. The nine winning artists received computers from a local computer store and public recognition for their designs.

District Department staff indicated that while the service was and continues to be extremely successful, it has served an even greater purpose - as a catalyst to significantly increase systemwide ridership. The example given was that for a 20 percent increase in ridership on the U.S. 41 route a 10 percent increase in overall system ridership is gained.

\section{Sarasota County Area Transit (SCAT)}

The Sarasota County Transportation Authority functionally operates as the transit department of Sarasota County government. The transit system is informally known as the Sarasota County Area Transit system and uses the acronym "SCAT" for marketing purposes. SCAT is governed by a five member board of county commissioners. SCAT serves the urbanized portion of Sarasota County including the cities of Longboat Key, Sarasota, Venice, Englewood, and North Port. SCAT provided fixed route motorbus service and provides demand response services via a contracted operator.

\section{U.S. 41 (South Tamiami Trail) - FPN \# 4071071}

\section{Project Scope}

Route 17 is SCAT's principal spinal route in Sarasota County, connecting downtown Sarasota to downtown Venice via U.S. 41 (Tamiami Trail). SCAT Route 17 serves the most densely populated, intensively utilized land in the county, including two large hospitals, three regional malls, two large downtowns, and hundreds of service establishments. With hourly service, some trips are actually overloaded at certain points along the route during particular times of the day. As the land uses along this corridor continue to intensify, SCAT's planning and operations personnel have forecast that with no improvements made, "crush loads" will begin to occur within the next two years. Some passengers may even be left stranded for an hour to wait for the next bus if service is not added. At the same time, SCAT also saw an opportunity for increasing ridership in the corridor by offering more frequent service. 
This project is for the purchase of four new 35 -foot transit coaches to enable SCAT to operate at 30 minute frequencies along the U.S. 41 corridor from Sarasota to Venice. Additional expenses include a doubling of operating expenses for the route, promotional and marketing activities. The Department is funding 50 percent of the project cost of $\$ 534,000$ ( $\$ 267,000$ state/ $\$ 267,000$ local).

\section{Project Milestones/Goals}

SCAT has established criteria for project success that includes ridership on the entire corridor at or above the SCAT minimum standard of 16 passengers per hour and a 52 percent increase in existing route ridership (an increase of 123,370 passenger trips) during the first year; nine percent (or 32,440 additional passenger trips) in the second year; and a stabilization of ridership in the third year.

\section{Service Description}

To provide 30 minute service along the U.S. 41 corridor from downtown Sarasota to downtown Venice, integrating the service into the existing SCAT Route 17.

\section{Progress}

This is a new project. The JPA has not been signed and therefore, service has not begun.

\section{Manatee County Area Transit (MCAT)}

Manatee County Area Transit is a division within the Community Services Department of Manatee County government. MCAT is governed by the Manatee County Board of County Commissioners. The system provides service to the urbanized areas of Manatee County. MCAT operates fixed route motorbus service as well as demand response transportation services.

\section{Manatee Avenue/SR 64 Corridor Project - FPN \# 4071171}




\section{Project Scope}

This project consists on adding one bus to the Manatee Avenue/SR 64 corridor (MCAT Route 3). The project includes operating assistance, promotion and marketing of service. The project is expected to improve headways and contribute towaqrd a reduction of vehicle congestion along the SR 64 corridor. The Department is funding 50 percent of the total project cost of $\$ 522,000$ ( $\$ 261,000$ state $/ \$ 261,000$ local).

\section{Project Milestones/Goals}

The primary goal is to increase ridership on MCAT's fixed route system, specifically for Routes 3, 5 and 6 . The benchmarks established for ridership on these routes are 170,777 annual passengers and 15.8 passengers per revenue hour.

\section{Phase I Goals (3/31/01)}

A 15 percent increase in ridership over the benchmark period bringing the project routes total to 196,394 passengers. This represents an average of 12.4 passengers per revenue hour for the three routes.

\section{Phase II Goals (3/31/02)}

An additional 15 percent increase in ridership over the Phase I period bringing the project routes total to 225,853 passengers at an average of 14.2 passengers per revenue hour.

\section{Phase III Goals (3/31/03)}

An additional 15 percent increase in ridership over Phase II bringing ridership to 259,731 passengers with an average of 16.4 passengers per revenue hour.

\section{Progress}

This is a new project. The JPA was signed on March 3, 2000.

\section{District 2 Project Summaries}


During the project time period from July 1, 1993 through December 31, 1999, the FDOT District 2 Office awarded $\$ 580,335$ in transit corridor funds. The project summaries are as follows:

\section{Jacksonville Transportation Authority (JTA)}

The Jacksonville Transportation Authority (JTA) is an independent authority governed by a seven member board of directors. Three of those members are appointed by the Governor of Florida, three are appointed by the Mayor of Jacksonville, and the final member is the FDOT district secretary. JTA provides services in Duval and northern Clay County. JTA directly operates fixed-route motorbus and automated guideway service. Demand responsive services are provided via contract with private providers.

\section{Park-N-RideCommuter Express Routes - WPI \# 2814311}

\section{Project Scope}

This project provides enhanced express commuter service to park-n-ride lots along highly congested areas in the north, south, and southwest areas of the City of Jacksonville, specifically, but not limited to the areas of Baymeadows, Southpoint, Deerwood, the Barnett Office Park, and the Naval Air Station.

\section{Project Goals/Milestones}

Milestones were established for the project as follows:

First Year - Develop public awareness campaign/schedules for the express services; prepare for the implementation of the express service; and implement.

Year Two - $\quad 1^{\text {st }}$ Quarter: Increase service express services and ridership by $1 \%$ $2^{\text {nd }}$ Quarter: Increase ridership by $1.5 \%$ $3^{\text {rd }}$ Quarter: Increase ridership by $1.5 \%$ $4^{\text {th }}$ Quarter: Increase ridership by $1 \%$ and review project.

The criteria for the overall success of the project will be measured in the increased patronage of park-n-ride lots and mass transit services.

\section{Service Description}


Service is provided between Orange Park and the Naval Air Station through the areas mentioned above. Two trips in the "primary direction" are provided during the a.m. peak period and two trips in the "primary direction" are provided during the p.m. peak period on the established express routes.

\section{Progress}

The primary expenses that have been paid by FDOT were for marketing and promotional activities and the purchase and installation of 13 automated passenger counters (APCs). As of the latest billing, made in October 1999, $\$ 74,396$ had been spent on the project. Ridership data was not provided in the invoicing support materials.

\section{Gainesville Regional Transit System (RTS)}

Gainesville Regional Transit System (RTS) is a department within the City of Gainesville. The board of directors is the City of Gainesville Board of City Commissioners who are responsible for policy decisions regarding RTS as well as other City of Gainesville departments. RTS has an advisory board that is composed of citizens from the community who provide input to the City Commission regarding the transit system and its structure. RTS provides service within the City of Gainesville and adjacent areas of Alachua County. RTS directly operates fixed-route motorbus service and provides demand responsive services via contract with private providers.

\section{SW Gainesville Enhanced Bus Service - WPI \# 2810791}

\section{Project Scope}

The objective of this project is to increase weekday service on SW 20th Avenue from the Oaks Mall to the University of Florida (UF) campus (Route 20, old Route 4); on SW $13^{\text {th }}$ Street from Landings to UF campus (Route 13, old Route 3); on SW $23^{\text {rd }}$ Terrace/Archer Road to UF (Route 9); and on $34^{\text {th }}$ Street/Campus Club Apartments to UF (Route 12, old Route 9). The service enhancements include increased service hours, frequency of service, and number of buses.

\section{Project Milestones/Goals}


There were no project milestones/goals included in the documentation in the project file. However, district staff personnel indicated that goals were not established for the project initially because RTS needed to review the performance of the project following the first year of operations. Once the performance and operating characteristics of the route are well established and baseline data are available, goals and objectives will be established for the project.

\section{Service Description}

The UF Express provides express bus service between the Oaks Mall and the University campus. This route was created to provide an alternative to on-campus parking. The service is provided free to UF students, and UF and Shands faculty and staff members. The hours of operation are Monday through Friday from 6:20 a.m. to 8:55 a.m. and from 3:40 p.m. to 6:15 p.m. Service was originally provided every 20 minutes but was increased to every 15 minutes in the Spring of 1999.

In the Spring of 1998, Route 3 was improved by adding one bus, increasing frequency from 60 to 45 minutes. Route 9 was divided into two new routes (Routes 9 and 12) going from 30 to 15 minute frequency and from two buses to three on Route 9 and three buses on Route 12. The headways on Route 4 were improved from 30 to 15 minutes with an adjustment from two to four buses.

During the Summer of 1998, service was enhanced through the addition of three buses: one on Route 3 (now called Routes 13 and 15); and two buses on Route 9 (one on the new Route 9 and one on Route 12).

Beginning in the Fall of 1998, students were permitted to ride the bus for free by showing their student card resulting in tremendous ridership increases. As a result, Route 3 (new Routes 13 and 15) was enhanced with one more bus, with rerouting resulting in a 15 minute headway during peak hours (Route 13); Route 9 (new Routes 9 and 12) was enhanced with eight more buses (four for each route) with 10 minute headways; and Route 4 (new Route 20) added two additional buses, reducing headways to 15 minutes. By the end of September 1998, Route 9 was reduced by two buses, leaving six total buses (three for each route).

In January 1999, a new route, the Lexington Express, was added providing service in the morning and afternoon peak hours within the same area as Route 9. The Lexington 
Express is served by one bus that runs on 30 minute headways from two different apartment complexes to the University.

\section{Project Progress}

Ridership has dramatically increased since the implementation of the enhanced service. The following table identifies the changes in ridership from 1997 to 1999 (includes only those months with significant student populations due to the focus on student transportation), based on data provided in the most recent report submitted in May 1999.

\section{Ridership 1997-1999}

Routes 3, 9, and 4 (20), Inclusive (January - April; September - December)

\begin{tabular}{|l|r|r|r|r|}
\hline Month & 1997 Ridership & 1998 Ridership & 1999 Ridership & \% Change \\
\hline January & 33,236 & - & 146,076 & $339.51 \%$ \\
\hline February & 34,126 & - & 153,541 & $349.92 \%$ \\
\hline March & 28,981 & - & 135,772 & $368.49 \%$ \\
\hline April & 29,337 & - & 126,308 & $330.54 \%$ \\
\hline September & 23,895 & 60,282 & - & $152.28 \%$ \\
\hline October & 70,433 & 158,463 & - & $124.98 \%$ \\
\hline November & 48,969 & 117,112 & - & $139.15 \%$ \\
\hline December & 38,157 & 73,408 & - & $92.38 \%$ \\
\hline Total & 307,134 & 409,265 & 561,697 & \\
\hline
\end{tabular}

Note: Service enhancements implemented in Fall 1998. Data available through April 1999.

In summary, this enhancement project has significantly increased the transit ridership within the major transportation corridors in Southwest Gainesville, alleviating traffic congestion within the area and reducing parking demands within the University area.

Night Bus Service - "Later Gator” - WPI \# 2810829

Project Scope 
At the time this service was implemented, service on RTS bus routes ended between 8:00 p.m. and 9:00 p.m., Monday through Friday. On Saturdays, service ended at between 6:00 p.m. and 7:00 p.m. The University of Florida Student Government approached RTS identifying a need for students to have access to safe, reliable, and comfortable public transit much later into the evening and early morning hours.

The UF Student Government, UF Administration, and the City of Gainesville established an objective to provide public transit service to meet the mobility requirements of UF students by operating all sutdent oriented bus routes until at least midnight on a six day per week basis and that additional after midnight service be operated to provide a safe ride home for students after regular bus service stops.

\section{Project Milestones/Goals}

There were no project milestones/goals included in the documentation in the project file. However, district staff personnel indicated that goals were not established for the project initially because RTS needed to review the performance of the project following the first year of operations. Once the performance and operating characteristics of the route are well established and baseline data are available, goals and objectives will be established for the project.

\section{Service Description}

Prior to full implementation of the service, interim service was provided on selected weekends during the Fall Semester, 1998. The interim service consisted of modified existing routes linking a number of on- and off-campus student housing areas with destinations cush as the Reitz Union, the libraries, downtown, the Oaks Mall, Butler Plaza, etc. A successful interim service period justified the full implementation of the service.

The "Later Gator" began running on Thursday, September 3, 1998. During the spring of 1999, this service was provided on Thursday, Friday and Saturday evenings, running every 10 minutes from the Reitz Union to the RTS Downtown Plaza. Five routes were established using nine buses. Buses operate with 15 minute headways, except for the campus to downtown connector which operates every 10 minutes. The hours of operation is from 9:30 p.m. to 3:00 a.m. University of Florida students ride for free. All other passengers pay $\$ 1.00$ per ride or $\$ 0.50$ for all other students, the disabled, and the elderly. 


\section{Progress}

The following table identifies the ridership totals and average passengers per hour for the service with data for September 1998 through April 1999.

\begin{tabular}{|l|r|r|}
\hline \multicolumn{1}{|c|}{ Month } & \multicolumn{1}{c|}{ Ridership } & Passengers/ Hour \\
\hline September 1998 & 2,561 & 8.9 \\
\hline October 1998 & 5,139 & 14.3 \\
\hline November 1998 & 7,244 & 17.6 \\
\hline December 1998 & 3,770 & 17.5 \\
\hline January 1999 & 6,677 & 33.7 \\
\hline February 1999 & 7,394 & 37.3 \\
\hline March 1999 & 3,912 & 19.8 \\
\hline April 1999 & 6,956 & 32.4 \\
\hline Total & $\mathbf{4 3 , 6 5 3}$ & --- \\
\hline Average/Month & $\mathbf{5 , 4 5 7}$ & $\mathbf{2 2 . 6 9}$ \\
\hline
\end{tabular}

Significant ridership increases were reported through the period. Decreases in December 1998 and March and April 1999 can be attributed to low student populations during the University's Winter and Spring breaks, respectively.

\section{Tower Road Corridor Service - WPI \# 2810830}

\section{Project Scope}

The scope of the project included the enhancement of bus service within the Tower Road Corridor, including the development and implementation of the service. FDOT funds are used for operating and capital costs association with the service.

\section{Project Milestones/Goals}

There were no project milestones/goals included in the documentation in the project file.

Service Description 
Service is provided via Routes 1 and 75 running between the University of Florida and the Oaks Mall along Archer Road and Tower Road (SW $75^{\text {th }}$ Street); Route 4 running from downtown to Shands; and segments of Route 5 running from Cedar Ridge to the Oaks Mall.

Route 1 provides service every 30 minutes during peak hours on weekdays and hourly service during off-peak. Service is provided every hour on Saturdays and holidays. Route 4 provides service every 30 minutes during weekdays and Saturdays. Route 5 provides service every 30 minutes during peak hours and every 40 minutes during offpeak hours. Route 75 provides service every 30 minutes during peak hours on weekdays and hourly service during off-peak hours.

\section{Progress}

In Spring 1998, Route 1 carried a total of 60,293 passengers from the month of January through April, with an average of 24.1 passengers per hour. The ridership data for the segment of Route 5 included in the enhanced service is not available.

In Spring 1999, Route 1 carried a total of 60,514 passengers from January through April. The average boardings were 28.4 passengers per hour. Route 4 carried a total of 42,399 passengers over the same four month period, with an average of 28.3 passengers per hour. Route 75 carried a total of 42,414 passengers at an average of 20.2 passengers per hour.

Service availability was significantly increased between the spring of 1998 and the spring of 1999. Total in service hours increased from 3,414.3 hours in 1998 (January through April) to 5,728.1 hours in 1999 (January through April). Along with this increase in service was a corresponding increase in the overall cost to provide the service, from $\$ 131,451$ in the spring of 1998 to $\$ 220,528$ in the spring of 1999 .

This project is scheduled to be terminated on December 31, 2000. It is unknown whether a supplemental agreement will be established extending the project.

\section{District 3 Project Summaries}

During the project time period from July 1, 1993 through December 31, 1999, the FDOT District 3 Office awarded $\$ 1,342,462$ in transit corridor funds to two projects. The project summaries are as follows: 


\section{Escambia County Area Transit (ECAT)}

\section{Davis Highway Transit Corridor Project (Route 19) - FPN \# 22582518401}

Project Scope

The project scope is to provide 30 minute express bus service on Davis Highway between the ECAT transfer facility and West Florida Regional Medical Center to relieve congestion in the corridor. During the first year of operation, an aggressive marketing campaign was established to promote ridership among commuters and shoppers for Davis Highway businesses, the University Mall and West Florida Regional Medical Center.

Project Milestones/Goals

The goals established for the program include the following:

\begin{tabular}{|c|c|c|c|c|}
\hline & $\underline{F Y} 1997$ & FY 1998 & $\underline{F Y 1999}$ & FY 2000 \\
\hline Passengers/Mile & .70 & .77 & .85 & 1.3 \\
\hline Revenue/Mile & $\$ 0.42$ & $\$ 0.46$ & $\$ 0.50$ & $\$ 0.80$ \\
\hline
\end{tabular}

The following table summarizes the annual goals established with corresponding averaged system performance data for FY 1997 through FY 1999.

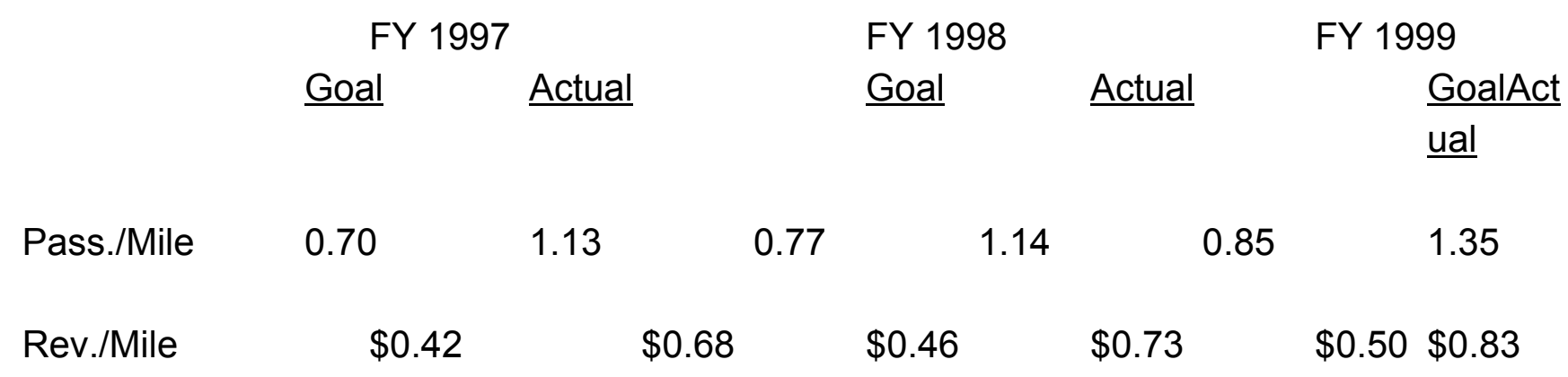

Service Description 
Service is provided at 30 minute intervals between the ECAT transfer facility and the West Florida Regional Medical Center via Davis Highway.

\section{Progress}

This project has been significantly successful in meeting and exceeding the goals established. Ridership and route revenue continue to increase at a healthy rate. The following annualized ridership and revenue data was provided by ECAT to the District 3 Public Transportation Office.

\begin{tabular}{lccccc} 
Fiscal Year & \multicolumn{2}{c}{$\begin{array}{c}\text { Ridership } \\
\text { Increase }\end{array}$} & $\underline{\text { over FY 97 }}$ & $\underline{\text { Revenue }}$ & over FY 97 \\
FY 1997 & 109,099 & N/A & $\$ 66,044$ & N/A \\
FY 1998 & 147,342 & 35.1 & $\$ 93,863$ & 42.1 \\
FY 1999 & 166,963 & 53.0 & $\$ 103,401$ & 56.6
\end{tabular}

\section{Blue Angel Highway Corridor Project (Route 18) - FPN \# 22583418401}

\section{Project Scope}

The Blue Angel Express transit corridor project was developed to provide express service along the heavily congested central northeast/southwest corridor within Pensacola. The original JPA executed on January 2, 1993 provided $\$ 200,000$ in funding to support the first year of operation of the express bus service. A supplemental JPA was signed on May 23, 1994 adding an additional $\$ 200,000$ to support the second year of operation. In 1996, ECAT requested an annual allocation of $\$ 150,000$ for fiscal years 1998 through 2000 to continue the project with additional marketing efforts and enhanced service levels including limited Saturday and Sunday service, the continuation of a park-and-ride lot feeder system, and airport service to accommodate incoming/outgoing Naval Air Station personnel.

\section{Project Milestones/Goals}

The goals originally established for the program include an annual increase of 5 percent in both ridership and revenue over the 1996 base year as follows: 
Ridership

16,800

17,640

18,500

19,500

Revenue

$\$ 11,140$

$\$ 11,700$

$\$ 12,285$

$\$ 12,900$

\section{Service Description}

The Blue Angel Express provides express bus service on the Blue Angel Highway, Monday through Friday with limited Saturday and Sunday service. The Blue Angel Express also serves park-and-ride lots along the corridor and also provides airport service to accommodate incoming/outgoing Naval Air Station personnel.

\section{Progress}

Actual annual ridership and revenues collected on the route for FY 1998 and FY 1999 are as follows:

\begin{tabular}{|c|c|c|c|c|}
\hline & 1998 Goal & 1998 Actual & 1999 Goal & 1999 Actual \\
\hline Ridership & 17,640 & 35,985 & 18,500 & 55,743 \\
\hline Revenue & $\$ 11,700$ & $\$ 29,637$ & $\$ 12,285$ & $\$ 41,184$ \\
\hline
\end{tabular}

As illustrated in the tables above, the Blue Angel Highway Corridor Project has been extremely successful in meeting and exceeding the goals established for the project. In 1998, ridership was 104 percent above the goal established and the revenue was over 153 percent above the established goal. Likewise, ridership and revenue in FY 1999 were also well above the goals established for the project.

Additional goals were established for passengers per mile and revenues per mile. The following table summarizes the annual goals established with corresponding averaged system data for FY 1998 and FY 1999.

$$
1998 \text { Goal } 1998 \text { Actual } 1999 \text { Goal } 1999 \text { Actual }
$$
Passengers/Mile
0.28
0.58
0.75
0.69 
Again, the Blue Angel Highway project has well exceeded the goals established in FY 1998. In FY 1999, the project fell short of the goals established. However, the system data does show an improvement over FY 1998. In addition, information contained in the most recent status reports provides that the net cost per passenger for the route decreased from $\$ 3.96$ per passenger in FY 1998 to $\$ 2.87$ per passenger in $F Y 1999$, a 27.5 percent decrease. Considering all factors, this project has been significantly effective in meeting the overall goals established for the corridor.

\section{District 4 Project Summaries}

During the project time period from July 1, 1993 through December 31, 1999, the FDOT District 4 Office awarded $\$ 1,125,000$ in transit corridor program funds to Broward County Transit. The project summary is as follows:

\section{Broward County Transit (BCT)}

The Broward County Mass Transit Division is a division of the Broward County Community Services Department. The Transit Division is governed by the Board of County Commissioners of Broward County. The service area of BCT is Broward County. Connections are made to Palm Tran in Boca Raton and to Miami-Dade Transit Agency in North Miami Beach and Carol City. The system directly operates fixed-route motorbus service as well as contracting for some services such as Tri-Rail Commuter Rail feeder bus service and community service to Cooper City, Margate, Pembroke Pines, Coconut Creek, Miramar, Hillsboro Beach, Deerfield Beach, Davie, and TSI which provides express peak service from western Broward County to downtown Ft. Lauderdale. In addition, paratransit service is offered via contract with a private provider.

\section{The Broward Urban Shuttle (BUS) and Western Express - WPI \# 4811331}

\section{Project Scope}

The original contract, dated June $27^{\text {th }}, 1994$, was for $\$ 700,000$ to be used to develop a neighborhood shuttle that would feed into BCT's mainline. Included in the costs were contracted services, lease vehicles, marketing, and a passenger and preliminary ridership report. A supplemental agreement was signed on July 15, 1996 providing an 
additional $\$ 200,000$ to the project to expand the service provided and purchase and install bus shelters. In April 1999 a second supplemental agreement was signed providing an additional $\$ 200,000$ for service expansion and operation and $\$ 225,000$ for the purchase of electric buses.

\section{Project Milestones/Goals}

The following goals have been established for the project:

Goal 1: To increase mass transit accessibility.

\section{Objectives:}

- Provide and encourage intermodal access to Ft. Lauderdale Tri-Rail Station, the FDOT park-and-ride lot, and Lauderhill Mall.

- Provide enhanced accessibility for neighborhood residents according to their expressed needs.

Goal 2: Increase productivity/ridership in designated residential communities contiguous to the corridor.

\section{Objectives:}

- Increase transit ridership by $25 \%$ within the expanded study area.

- Decrease transit travel times along the Broward Boulevard Corridor by examining the feasibility of enhanced fixed route service along major corridors that intersect the study area.

- Schedule timed transfers between fixed-route services and neighborhood service.

Goal 3: Divert paratransit trips onto the fixed-route service or onto alternative neighborhood circulator service.

\section{Objectives:}

- Maintain statistics on wheelchair ridership.

- Develop a list of comprehensive public participation plan.

- Prepare a comprehensive plan for marketing and promotion of services within the study area. 
- Coordinate marketing efforts with Tri-Rail Marketing staff.

- Attend meetings with affected neighborhood and homeowners' associations.

- Conduct regular on-board and community surveys to assess the suitability of the transit services being provided.

- Evaluate community input to enhance transit services and improve passenger amenities.

- Include representatives of all transportation modes in promotional processes (e.g. Tri-Rail, Gold Coast Commuter Services, County Bicycle Coordinator, etc.).

Service Description

The Mini BUS provides door-to-door service to residents who live in an area bounded by Sunrise Boulevard to the north; Northwest $27^{\text {th }}$ Avenue/Riverland Road and the TriRail Station to the east; Davie Boulevard to the south and State Road 7-Lauderhill Mall to the west.

\section{Progress}

Passenger and community surveys were completed in the Winter of 1998. A survey report was developed, dated February 1999. 72 surveys were distributed to riders of the BUS with 71 responses. 9,074 surveys were mailed to the community. 8,646 were delivered successfully and 522 were completed and returned. The rider survey asked questions related to trip purpose, car availability, demographics (age), and service rating. The community survey focused on the communities awareness of the BUS, the vehicle availability, trip purpose, and demographics.

The most recent progress report was received by the Department in July 1999 for the fourth quarter of FY 1999 (April through June) and included year-to-date statistics. Compared with the prior year, ridership on the BUS and the Southwest Broward Express increased 11.6 percent (a 19.1 percent increase for the Southwest Express and a 6.7 percent increase on the BUS). Comparing the fourth quarter of FY 1997 (service began in late March 1997) to the fourth quarter of FY 1999, total ridership on the routes increase 114 percent, with the BUS ridership increasing 102 percent and the Southwest Broward Shuttle increasing by 127 percent. Favorable performance data for both routes and for the project.

\section{District 5 Project Summary}


During the project time period from July 1, 1993 through December 31, 1999, the FDOT District 5 Office awarded $\$ 10,000$ in transit corridor program funds to LYNX. The project summary is as follows:

\section{LYNX (Central Florida Regional Transportation Authority)}

The Central Florida Regional Transportation Authority (LYNX) is an independent authority created under Florida Statute, and is governed by a Board of Directors with members from Orange, Seminole and Osceola Counties, the Cities of Orlando, Altamonte Springs, and Kissimmee, the FDOT District Five Secretary, and two gubernatorial appointees. LYNX operates fixed-route motorbus service, and is the CTC for the three county region providing demand-responsive service.

\section{I-4 Express Survey - WPI \#5815144}

Project Scope

This project was undertaken to determine the relative feasibility of establishing express bus service along Interstate 4 between Volusia, Seminole and Orange Counties. The total project budget for the survey was $\$ 10,000$ (100\% state funds).

\section{Project Milestone/Goals}

To develop and conduct the survey and provide a written summary of the results.

Service Description

Not Applicable

\section{Progress}

In May 1995, origin and destination surveys were conducted at three I-4 interchanges in Volusia County. The survey was established to interview only those drivers who would be traveling westbound (toward Orlando) on I-4. The survey instrument asked drivers to identify the purpose of their trip, the number of times the trip was made during a week, the closest major intersection to their home, the closest intersection to their work place, the number of vehicles owned by the household, and whether or not they would ride a non-stop bus from a Deltona area park-and-ride location to their work destination. The 
interviewer was asked to make a number of observations including the estimated age range within which the person fell, the sex of the driver, their ethnic origin and the auto occupancy.

Of those interviewed 95 to 97 percent were traveling to the Orange County/Seminole County area. When asked if they would ride a non-stop bus from a Deltona area parkand-ride location to their work destination, 39 to 44 percent indicated that they would consider riding a non-stop bus to their work area.

(LYNX and VOTRAN have since implemented express bus service between Volusia and Orange/Seminole Counties with FDOT Service Development funds.)

\section{District 6 Project Summaries}

During the project time period from July 1, 1993 through December 31, 1999, the FDOT District 6 Office awarded $\$ 11,585,148$ (includes $\$ 2,066,944$ in funds awarded to the Northwest $27^{\text {th }}$ Avenue MAX and Flagler MAX projects prior to July 1, 1993) in transit corridor program funds to Miami-Dade Transit Agency and the City of Miami Beach. The project summaries are as follows:

\section{Miami-Dade Transit Agency}

The Miami-Dade Transit Agency (MDTA) is a department of Miami-Dade County, and is governed by the Board of County Commissioners. MDTA operates fixed-route motorbus service, heavy rail and automated guideway services. Demand-response service is both directly operated and purchased.

\section{N.W. $27^{\text {th }}$ Avenue MAX - WPI \# 6819003}

\section{Project Scope}

In 1987, the Florida Department of Transportation completed a study of the N.W. $27^{\text {th }}$ Avenue/University Drive corridor in northern Dade and southern Broward Counties. The purpose of the project was to develop public transit operation treatments for implementation within this corridor. The study recommended several improvements to public transit in this corridor. One of the recommendations was a demonstration project using small buses to link residential areas within the N.W. $27^{\text {th }}$ Avenue corridor to the Metrorail stations. At the time, a similar service was being successfully demonstrated in 
the Kendall area (Kendall Area Transit (KAT)). To implement the recommendation, the Miami-Dade Transit Agency (MDTA) entered into a joint participation agreement with the Department for a project aimed at improving transit service in the N.W. $27^{\text {th }}$ Avenue corridor in northern Dade County.

The first step in the project was to define the N.W. $27^{\text {th }}$ Avenue corridor study area defined as an area bounded by the Dade-Broward County line on the north; SR-112 (Airport Expressway) on the south; I-95/Florida's Turnpike on the each and N.W. 57 $7^{\text {th }}$ Avenue on the west (except the area bounded by N.W. $119^{\text {th }}$ Street and N.W. $42^{\text {nd }}$ Avenue). The second step involved detailed market research in the study area. MDTA on-board surveys of current transit passengers and a random telephone survey of households in the study area helped determine the travel patterns of transit and nontransit travelers within the corridor. The survey findings indicated that there was a need for a limited, high-speed bus service to major N.W. $27^{\text {th }}$ Avenue corridor activity centers and the Metrorail.

\section{Project Milestones/Goals}

Two productivity measures were used to evaluate the project: average passengers per revenue hour and net cost per passenger. The resource-measurement goal of the project was for average boardings per revenue hour to be at least half of the average for comparable peer routes and for the net cost per passenger to be less than twice the average for comparable routes.

\section{Service Description}

With the potential market identified, the route design of the new limited stop service on N.W. $27^{\text {th }}$ Avenue was finalized. The route was designed to operate between the North Dade neighborhood west of Calder Race Track and Martin Luther King (MLK), Jr. Metrorail Station via N.W. $27^{\text {th }}$ Avenue.

The new service, the $27^{\text {th }}$ Avenue MAX, was inaugurated on December 9, 1991. The route operated every 15 minutes during peak periods as a limited stop service along N.W. 27 Avenue. The service level remained unchanged during the demonstration period.

Service was provided along N.W. $27^{\text {th }}$ Avenue between N.W. $211^{\text {th }}$ Street and the MLK Metrorail Station. There were 10 stops spaced an average of one-mile apart including 
stops at major activity centers and tranfer points. At the north end of the route, local stops were placed at shorter intervals along a loop via N.W. $207^{\text {th }}$ Street and N.W. $211^{\text {th }}$ Street between $27^{\text {th }}$ and $32^{\text {nd }}$ Avenues. The alignment remained unchanged with the exception of the following modifications:

C In April 1994, the service was extended west from N.W. $32^{\text {nd }}$ Avenue to N.W. $37^{\text {th }}$ Avenue between N.W. $207^{\text {th }}$ and $211^{\text {th }}$ Street to serve the Vista Verde neighborhood. This improvement was in response to requests at MDTA community meetings in the northwest Dade area.

C In November 1994, several morning and afternoon trips were extended south from the MLK Metrorail Station to N.W. $36^{\text {th }}$ Street and $27^{\text {th }}$ Avenue to link passengers ot the airport.

C In August 1996, a stop was added at Ali Baba Avenue in Opa-Locka.

Minor running time adjustments were implemented through the project to improve service reliability to account for changing traffic conditions in the corridor.

The minibus vehicles were so successful in attracting potential riders and building a steady base of passengers that MDTA assigned full size (45 seat) transit coaches to the route in July 1993 to provide additional capacity.

\section{Progress}

For the first two years of operation, ridership steadily rose from slightly over 300 boardings per day to almost 700 boardings per day in the Winter of 1993/1994. From that time through the last quarter of the project, ridership declined somewhat to approximately 550 riders per day. However, while ridership declined during the period, actual transit ridership in the corridor increased by 3.7 percent from the Winter of 1991, prior to the start of the $27^{\text {th }}$ Avenue MAX to the Winter of 1997 , the last quarter of the project.

Metrorail also showed increasing ridership since the implementation of the $27^{\text {th }}$ Avenue MAX. Boardings at the MLK Metrorail Station increased by 16 percent from the Winter of 1991 to the Winter of 1997 . Total Metrorail ridership increased only 1 percent during the same time period. 
The $27^{\text {th }}$ Avenue MAX was terminated by the Department in the Winter of 1997 due to low ridership.

\section{Flagler MAX - WPI \# 6810184}

Project Scope

The Flagler MAX project was established in November 1991 through a JPA with the FDOT. The project purpose is to reduce congestion along the Flagler Street corridor from downtown Miami to Miami Beach.

\section{Project Milestones/Goals}

The resource management goal of passengers per revenue hour was to be at least onehalf the average of comparable peer routes (the Biscayne MAX and the $27^{\text {th }}$ Avenue MAX); and the cost per passenger trip was to be less than twice the average on comparable routes.

\section{Service Description}

The Flagler MAX is a limited stop express bus route from west Dade County to downtown Miami primarily through the Flagler Street corridor and to Miami Beach via the MacArthur Causeway. It operates every 15 minutes during weekday rush hours.

\section{Progress}

The Flagler MAX compares favorably to the peer routes established for the project. During the last report available for the project (April 1, 1999 through June 30, 1999), average daily ridership was 1,726 , a two percent increase above the same period within the prior fiscal year and a three percent increase above the prior quarter.

\section{South-Dade Busway - WPI \# 6810309}

\section{Project Scope}

The scope of this project is to provide express service, within exclusive bus lanes, along the US Highway 1 corridor. 


\section{Project Milestones/Goals}

The resource management goal of passengers per revenue hour was to be at least onehalf the average of comparable peer routes and the cost per passenger trip was to be less than twice the average on comparable routes.

\section{Service Description}

The South-Dade Busway connects the Dadeland South Metrorail Station and Cutler Ridge, providing exclusive roadway lanes for buses operated by or for the Miami-Dade Transit Agency and emergency vehicles. Areas east, west, and south of the Busway are served by five bus routes also operated with transit corridor funds through this project: the Busway MAX; Busway Local; Coral Reef MAX, Saga Bay MAX, and the 1 Busway (description and ridership information provided below). They offer local and limited-stop service on the Busway and in the neighborhoods between Florida City and the Dadeland South Metrorail Station.

\section{Progress}

The South-Dade Busway is one of the most successful transit corridor projects discussed within this report. The Busway corridor ridership continues in an upward trend. Average weekday corridor ridership for the most recently reported period (April 1, 1999 through June 30,1999 ) was 11,578 , a 10 percent increase over the average corridor ridership in the same reporting period for the previous year, and a 70 percent increase over the same period in 1996 (the year before the busway opened). Average weekend ridership for the most recent reporting period was 12,576, a 26 percent increase from the average ridership for the same period during the prior fiscal year, and a 118 percent increase over the same quarter in FY 1996.

\section{Ancillary Routes}

Busway MAX - The Busway MAX is a limited-stop route between Florida City and the Metrorail. The route operates on the Busway north of Cutler Ridge and along US 1 south of Cutler Ridge, serving Goulds, Homestead, and Florida City. Service between the S.W. $152^{\text {nd }}$ Street Busway Station and the Dadeland South Metrorail Station is nonstop during weekday rush hours. The route serves all Busway stations during off-peak. The Busway MAX operates every 15 minutes during weekday rush hours and every 30 minutes during off-peak. Average boardings per day during the most recently reported 
period (April through June) were 3,283 for weekdays, 2,905 for Saturdays, and 2,392 for Sundays. Average passengers per revenue hour was 28.4 passengers per weekday hour, 35.2 for Saturdays, and 29.0 for Sundays for the quarter ending June 30, 1999. The average cost per passenger was $\$ 1.57$ during the weekdays, $\$ 0.45$ on Saturdays, and $\$ 0.65$ for Sundays. The Busway MAX continues to meet and exceed the resourcemeasurement goals of average passengers per revenue hour (at least one-half the average of comparable peer routes) and the average net cost per passenger (less than twice the comparable average of the peer routes).

Busway Local - The Busway Local operates on the Busway serving all Busway Stations between Cutler Ridge and the Dadeland South Metrorail Station, seven days per week. Full-sized transit coaches are used during weekday rush hours and mini-buses are used at all other times. The Busway Local operates every 15 minutes during weekday rush hours and every 30 minutes during off-peak. Average boardings per day during the most recently reported period (April through June) were 1,581 for weekdays, 1,105 for Saturdays, and 972 for Sundays. Average passengers per revenue hour was 33.4 passengers per weekday hour, 34.2 for Saturdays, and 30.1 for Sundays for the quarter ending June 30,1999 . The average cost per passenger was $\$ 1.01$ during the weekdays, $\$ 0.65$ on Saturdays, and $\$ 0.69$ for Sundays. The Busway Local continues to meet and exceed the resource-measurement goals of average passengers per revenue hour (at least one-half the average of comparable peer routes) and the average net cost per passenger (less than twice the comparable average of the peer routes).

Coral Reef MAX - The Coral Reef MAX provides limited stop service seven days a week service between Country Walk and the Dadeland South Metrorail Station via S.W. $152^{\text {nd }}$ Street and the Busway. The route provides service to the MetroZoo during its operating hours. The service, provided by mini-buses, runs every 20 minutes during weekday rush hours, every 45 minutes during weekday off-peak, and every 40 minutes on weekends.

Average boardings per day during the most recently reported period (April through June) were 1,037 for weekdays, 592 for Saturdays, and 339 for Sundays. Average passengers per revenue hour was 23.8 passengers per weekday hour, 22.6 for Saturdays, and 12.9 for Sundays for the quarter ending June 30, 1999. The average cost per passenger was $\$ 0.92$ during the weekdays, $\$ 1.12$ on Saturdays, and $\$ 2.52$ for Sundays. 
The Coral Reef Max quarterly boarding averages for the most recent reporting period were down slightly over the prior quarter. While weekday average boardings remained the same, Saturday and Sunday boarding declined by five percent and 19 percent respectively. It is suggested that this decline, similar to one experienced during the same quarter as last year, is most likely due to seasonal fluctuations.

Although the Coral Reef MAX has experienced a slight decrease in boardings, it meets the target goals of average passengers per revenue hour (at least one-half the average of comparable peer routes) and for average net cost per passenger (less than twice the comparable average.

Saga Bay MAX - The Saga Bay MAX is a limited stop, weekday rush hour service between Saga Bay and Metrorail. The route, operated by mini-buses, serves Busway stations between S.W. $168^{\text {th }}$ Street and the Dadeland South Metrorail Station. Service is every 15 minutes during weekday rush hours.

Average boardings per day during the most recently reported period (April through June) were 344 (only operates on weekdays). Average passengers per revenue hour was 20.2 for the quarter ending June 30,1999 . The average cost per passenger was $\$ 1.17$.

Average boardings declined 40 percent from last quarter, although ridership is consistent with the levels experienced during the 1998 reporting year. Overall, the Saga Bay MAX meets and exceed the resource-management goals of the project.

1 Busway - The Route 1 Busway provides local service seven days per week between the South Miami Heights area, east Perrine, and Metrorail. The route serves all Busway stations between S.W. $168^{\text {th }}$ Street and the Dadeland South Metrorail Station. It operates every 15 minutes during weekday rush hours.

Average boardings per day during the most recently reported period (April through June) were 1,563 for weekdays, 907 for Saturdays, and 511 for Sundays. Average passengers per revenue hour was 21.0 passengers per weekday hour, 22.1 for Saturdays, and 17.6 for Sundays for the quarter ending June 30, 1999. The average cost per passenger was $\$ 2.13$ during the weekdays, $\$ 2.18$ on Saturdays, and $\$ 2.96$ for Sundays. 
The Route 1 Busway quarterly boarding averages were four percent below weekday ridership for the previous quarter, 15 percent below Saturday boardings, and 27 percent below Sunday boardings. While the previous quarter fell behind in passenger boardings, the Route 1 Busway continues to meet the resource-measurement goals established for the project. In the most recently submitted quarterly report, the Route 1 Busway met or exceeded the average for comparable peer routes on weekdays and weekends. It also met the goal for average net cost per passenger. This was the first quarter that the route met the target goal for Saturdays.

\section{City of Miami Beach}

The City of Miami Beach is a municipal government within Miami-Dade County.

\section{Miami Beach Electric Shuttle "Electrowave” Project - WPI \# 6810341}

Project Scope

The original scope of this project was to purchase and operate seven electric buses to link under-utilized City of Miami Beach parking facilities with a newly created park-n-ride program to help alleviate the congestion and parking problems in South Beach.

\section{Project Milestones/Goals}

The goals of this project are to:

C provide a cost effective and environmentally sensitive transportation alternative in the South Beach area.

C demonstrate the effectiveness of a public/private partnership in solving existing transportation problems.

C demonstrate the effectiveness of electric vehicle technology to address traffic congestion problems. 
$C$ increase the use of existing under-utilized City of Miami Beach parking facilities in the South Beach area.

The following are objectives to measure the project success:

C Operating cost of the shuttle service will be compared with the operating cost of traditional powered vehicles, with a criteria for success of having lower operating costs.

C $\$ 35,000$ in outside advertising will be obtained in the first year to promote the shuttle, rising to $\$ 85,000$ in the second year of operation.

C Operating performance in South Florida's climate will be compared to traditionally powered vehicles, with a criteria for success of better reliability.

C Parking utilization at the Seventh, Twelfth, and seventeenth street garages will increase by $5 \%$ during the first year, and $10 \%$ by the end of the second year of shuttle operation.

\section{Service Description}

The project supports the operation shuttle services in the South Beach area of Miami Beach 365 days per year. Service is provided by seven electric trolleys. Headways are anticipated to be between 8 and 10 minutes. On July 1,1999 a $\$ 0.25$ fare was instituted. Prior to that time, the shuttle provided free service.

\section{Progress}

The electric shuttle project known as the "Electrowave" had its dedication and inauguration reception on Friday, January 30, 1998 from 3:00 p.m. until 5:00 p.m.. At 7:00 p.m. on the $30^{\text {th }}$ of January, service began. The charging, storage and maintenance of the vehicles will be done by the City of Miami Beach fleet management department at a prefabricated building next to its facility on Terminal Island (at the eastern end of MacArthur Causeway). The City of Miami Beach is in the process of obtaining funding for the development of a permanent multi-modal center to be constructed at the terminus of MacArthur Causeway on Fifth Street. This will provide permanent shuttle terminal, along with storage, charging equipment, maintenance facilities, and a 750 plus parking facility. 
Shuttle drivers are provided by American Bus Lines - Red Top, a subsidiary of Coach USA. A total of 26 drivers have been hired for the 365 days per year/20 hours per day operation. American Bus Lines also provides dispatch, backup vehicles, as well as general operations assistance.

Vehicle tracking systems have been installed in each of the seven vehicles. This system provides accurate ridership counts and provides system management control for shuttle dispatch and operation. Each vehicle can be tracked by street location and nearest cross street. The system will also track and record service delays, movement, speed of the vehicle, direction, and safety problems.

In addition, an energy monitoring system has been installed in six of the seven vehicles that provides driver and vehicle performance summaries, battery energy-efficiency and depth of discharge histories, fuel reports, and battery recharge and driving profiles.

The City of Miami Beach has leased property at the terminus of the MacArthur Causeway, on the south side of Fifth Street, for a park and ride lot for Electrowave users. The Miami Beach TMA has worked with employers and employees in the shuttle service area to encourage the purchase of special parking permits that will allow them on this lot. Permits allow employees and employers the use of the lot from Monday through Saturday, 6 a.m. until 8 p.m., at $\$ 25$ per month, plus tax. With other City lots in the area charging $\$ 50$ per month for parking, this has been quite popular.

The Electrowave has been extremely popular, carrying 1,392,454 passengers in its first year of operation. In 1999, the trend continued with monthly passenger trips averaging 112,284 . If the trend continues, the second year of operation for the Electrowave will continue to be successful.

The most important aspect of this project is the public-private partnerships that have been created. Only 18.51 percent of the total project budget was FDOT funds (Transit Corridor and Service Development). The remaining budget was funded by the City of Miami Beach, Florida Power \& Light (FP\&L), the Florida Alliance for Clean Technologies (donation of the energy monitoring system along with FP\&L), the Florida Department of Environmental Protection, and the Clean Cities Coalition. Additional support was provided by the Miami Beach TMA, the Miami Beach Police Department, the Miami Dade Transit Agency, and the merchants and other employers in South Beach.

\section{District 7 Project Summaries}


During the project time period from July 1, 1993 through December 31, 1999, the FDOT District 7 Office awarded $\$ 4,500,204$ in transit corridor funds to HART, PSTA, and Pasco County (includes $\$ 1,269,493$ for the US 41 Corridor project that was originally awarded prior to July 1, 1993 but was continued through supplemental agreements and $\$ 2,270,00$ for the 200X that began under WPI \# 7813923 in April 1988). The project summaries are as follows:

\section{Hillsborough Area Regional Transit Authority (HART)}

The Hillsborough Area Regional Transit Authority (HART) was created in October 1979 as a subdivision of the State of Florida. HART's Board of Directors consists of eleven members. Hillsborough County appoints five members, the City of Tampa three members, the City of Temple Terrace one member, and the State of Florida appoints two members. The Board of Directors selects an Executive Director who appoints or promotes individuals to the various positions of responsibility within the organization. HART directly operates fixed-route motorbus service and provides paratransit services through the County's Share-A-Van program.

\section{Tampa/Clearwater Express Service via Courtney Campbell Causeway (200X) - WPI \# 7813923/\# 7814028}

\section{Project Scope}

This project began in August 1985 as the Gandy/Courtney Campbell corridor project providing intra-county services between Pinellas and Hillsborough Counties via the Gandy Boulevard/Gandy Bridge and Courtney Campbell Causeway corridors to relieve congestion within those corridors. In 1990, service along these corridors was reducted by 20 percent to "...maintain a balanced budget..." (due to low ridership). At the same time, fares were increased from $\$ 1.00$ to $\$ 1.50$. In October 1990 , the Gandy corridor portion of the project was transferred to the Pinellas Suncoast Transit Authority (PSTA) and became PSTA's 100X (discussed below). The Courtney Campbell Express remained with HART and became the 200X. Under WPI \#7813923, \$2,270,000 in state funds was provided to the project. The project is continuing through funding allocated to HART under WPI \# 7814025. 
The budget of $\$ 500,000$ (under WPI \# 7814025) is primarily for operation and administration of the project, but does include funds for the installation and/or construction of two passenger shelters; leasing of park-n-ride lot space at Clearwater Mall and marketing expenses.

\section{Project Milestones/Goals}

The goal originally established for the project was a $30 \%$ farebox recovery. In 1990 , the goal was changed to a $2 \%$ per year increase in ridership.

\section{Service Description}

This project provides commuter express bus service from downtown Tampa in Hillsborough County to Clearwater in Pinellas County. The service runs through the Westshore area of Tampa and utilizes the Courtney Campbell Causeway (SR 60) to cross Tampa Bay.

The 200X stops at Westshore once in the morning on the way to Tampa and once in the evening on the way out to Clearwater. Two midday trips also stop at Westhore. With the addition of a stop at Clearwater Mall greater accessibility is provided to mall patrons. It also allows for easy transfers between HART and PSTA bus routes 19, 60, and 63. The 200X then continues to Drew Street via US 19, serving the HART/PSTA park-andride lot located that the Drew Shopping Center.

\section{Progress}

The following table identifies ridership and farebox recovery trends since the first quarter of Fiscal Year 1991 (100X was separated between PSTA (the Gandy Express) and HART (the Courtney Campbell Express) in October 1990). In this table, the fiscal year begins on October 1 and ends on September 30.

$\begin{array}{lcc}\text { Fiscal Year } & \text { Estimated Annual Ridership* } & \begin{array}{c}\text { Average Farebox } \\ \text { Recovery Ratio }\end{array} \\ \text { FY } 1991 & 41,730 & 18.4 \% \\ \text { FY } 1992 & 44,460 & 26.4 \% \\ \text { FY } 1993 & 43,160 & 30.7 \% \\ \text { FY } 1994 & 48,685 & 30.2 \% \\ \text { FY } 1995 & \text { Not Available } & 26.1 \%\end{array}$


FY 1996

*Based on average daily boardings multiplied by 260 operating days per year (Monday through Friday, excluding holidays).

Annual ridership has fluctuated since October 1990, however, a gradual decline in ridership began in 1996 (although it may have occurred during FY 1995 - complete ridership data for FY 1995 was not provided in the progress reports). Since 1994, ridership has decreased 11.7 percent. The average farebox recovery ratio has also fluctuated through the period, peaking at 30.2 percent in FY 1994 and gradually decreasing in the years following to 19.9 percent in FY 1998, a decrease of 34.1 percent. The annual ridership goal of 2 percent over the previous year was met in FYs 1992 and 1994. The average farebox ratio goal of 30 percent was met in FYs 1993 and 1994.

\section{US 41 Corridor Improvement Project - WPI \# 7810010/\# 7814114}

\section{Project Scope}

This project was initiated in March 1992. The purpose of the project is to provide more frequent service in the US 41 corridor in Tampa by providing frequent north-south service north of downtown Tampa on transit. The fixed route service is designed to attract riders to bus service for the work commute as a congestion mitigation strategy with a goal to increase ridership and reduce congestion on the corridor.

A supplemental agreement was signed on July 15, 1996 providing an additional $\$ 200,000$ to the project to expand the service provided and purchase and install bus shelters. In April 1999 a second supplemental agreement was signed providing an additional $\$ 200,000$ for service expansion and operation and $\$ 225,000$ for the purchase of electric buses.

Project Milestones/Goals 
Goal 1: Increase transit ridership on routes participating in the project (Routes 1, 2, 7 , 12, 20X, 26X,50X, and 56X).

Performance Measure: Ridership will increase by 3 percent in 2000 on the eight participating routes.

Goal 2: Maintain a reasonable farebox recovery ratio.

Performance Measure: Maintain an average farebox ratio of at least 30 percent on local routes and 10 percent on express routes.

\section{Service Description}

In order to relieve congestion along the US 41 Corridor (defined as Nebraska Avenue and Interstate 275), a number of routes were established and are supported by funds received by HART from the FDOT. The routes participating in the project include the following:

Route 1 - providing north/south fixed route service between HART's downtown Marion Street Transit Parkway to North Boulevard and Bearss Avenue. Northbound departures begin from the Marion Street facility at 5:23 a.m. with 15 minute headways until 9:00 a.m. At that time, headways go to 30 minutes and then return to 15 minutes after 3:00 p.m. Service is available until 9:00 p.m. Southbound departures begin at 5:05 a.m. until 9:05 a.m. with 30 minute headways. After the 9:05 a.m. departure time, service is provided on an hourly basis, resuming 30 minute service at 3:30 p.m. until 9:05 p.m. Saturday service is provided from 6:29 a.m. until 8:29 p.m. with 30 minute headways. Hourly service is provided Sunday from 6:28 a.m. until 6:25 p.m.

Route 2 - providing north/south fixed route service between HART's downtown Northern Terminal to the University Area Transfer Center. Northbound departures begin at 5:00 a.m. with headways averaging 15 minutes. After 9:00 a.m. service is provided with 30 minute headways and returns to 15 minute headways after 3:00 p.m. Service is available until 10:00 p.m. Southbound departures begin at 4:45 a.m. until 8:30 a.m. with 15 minute headways. Headways are increase to 30 minutes from 9:00 a.m. until 10:50 p.m. Saturdays service is provided from 6:35 a.m. until 7:20 p.m. with headways that average 30 minutes. Southbound service is provided until 8:20 p.m. Hourly service is 
provided on Sunday from 6:35 a.m. until 6:25 p.m. northbound and 6:35 until 8:35 southbound.

Route 7 - providing north/south fixed route service between HART's Tampa downtown Washington Street Station to North Boulevard and Bearss Avenue. Northbound departures are provided from 5:23 a.m. until 7:21 p.m with headways averaging 30 minutes. Southbound departures begin at 5:15 a.m. until 7:15 a.m. with 60 minute headways. Saturdays service is provided from 6:28 a.m. until 7:23 p.m. with headways that average 60 minutes. Southbound service is provided until 7:55 p.m. Hourly service is provided on Sunday from 6:19 a.m. to 7:02 p.m. northbound and from 6:19 to 7:55 p.m. southbound.

Route 12 - providing north/south fixed route service between HART's downtown Tampa Northern Terminal to University Area Transfer Center. Northbound departures begin at 5:00 a.m. with headways averaging 15 minutes. After 9:00 a.m. service is provided with 30 minute headways until 3:00 p.m. From 3:00 p.m. until 4:00 p.m. service is provided with 15 minute headways. Service is available until 10:00 p.m. Southbound departures begin at 5:15 a.m. until 10:05 p.m. with an average headway of 30 minutes. Saturdays service is provided from 6:35 a.m. until 7:35 p.m. with headways that average 30 minutes. Southbound service is provided until 7:33 p.m. Hourly service is provided on Sunday from 6:35 a.m. until 7:35 p.m. northbound and 6:35 until 7:35 southbound.

Route 20X - providing north/south peak period express bus service from HART's park-n-ride lot facility in Lutz to Tampa General Hospital. Southbound departures begin at 6:10 a.m. from the $1^{\text {st }}$ Babtist Church in Lutz with an average headway of between 35 and 40 minutes until 7:10 a.m. There are 3 southbound departures. Northbound departures are provided from 3:50 p.m. until 5:05 p.m. with an average headway of between 35 and 40 minutes. There are 3 northbound departures. This route does not provide services on weekends. Major service centers for this express route include the $1^{\text {st }}$ Babtist Church Park-N-Ride-Lutz, Fletcher Plaza Park-N-Ride, the Tampa Tribune, and Tampa General Hospital.

Route 26X - providing south/north peak period express bus service from HART's park-n-ride facility in Lutz to Tampa General Hospital. Southbound departures begin at 6:10 a.m. from the $1^{\text {st }}$ Babtist Church in Lutz with an average headway of between 35 and 40 minutes until 7:10 a.m. There are 3 southbound departures. Northbound departures are provided from 3:50 p.m. until 5:05 p.m. with an 
average headway of between 35 and 40 minutes. There are 3 northbound departures. This route does not provide services on weekends. Major service centers for this express route include North Lakeview Park-N-Ride, Mission Bell Shopping Center, the Tampa Tribune, and Tampa General Hospital.

Route 50X - providing south/north peak period express service between HART's Citrus Park Park-N-Ride facility to the Marion Street Transit Parkway. There are two southbound departures from Citrus Park at 6:30 a.m. and 7:20 a.m. each with an average headway of 50 minutes. There are two northbound departures from the Marion Street Transit Parkway at 4:40 p.m. and 5:15 p.m. with a 35 minute headway. This route does not provide services on weekends. Major service centers for this express route include Citrus Park Park-N-Ride facility, Carrollwood Park-N-Ride facility, Casey Park-N-Ride facility, and Orange Grove Park-N-Ride facility.

Route 56X - providing northbound peak period express service between Tampa General Hospital and Citrus Park Park-N-Ride facility. There is one northbound departure at 5:30 p.m. from Tampa General. No southbound travel is available. (Service will be eliminated in April 2000 due to low ridership.)

\section{Progress}

In a status report for the project, dated November 1999, it was reported that farebox recovery averaged 27 percent. Also in that report, it was suggested that the $56 \mathrm{X}$ be eliminated and that the funds that had been spent on the route be used to provide extended evening service hours on the 20X and the 50X. In the justification prepared by the district office in October 1999 for a budget increase, it was stated that "... This project has contributed to increasing and stabilizing transit ridership on all routes participating in this project..."

\section{Oldsmar/Tampa Express Service - FPN \#40647918401}

\section{Project Scope}

The purpose of this project is to provide express service within Hillsborough County from Net Park through Downtown Tampa to Oldsmar. This project is needed to respond to employment growth and congestion in the Tampa/Oldsmar corridor. At the present time, there is no direct transit service from Tampa to Oldsmar. Oldsmar's industrial and manufacturing industries have job openings that cannot be filled. Employers express 
interest in whether public transportation would have an impact on reducing their job vacancies. HART also received petitions from riders on Route 200X, Westchase area residents, and others commuting from west of Oldsmar to downtown Tampa requesting direct transit service.

The project budget is $\$ 125,000$, including $\$ 100,000$ for the operation of the express service and $\$ 25,000$ for marketing. The project is 100 percent state funded. The JPA was executed on November 22, 1999 with service anticipated to begin by April 2000.

\section{Project Milestones/Goals}

There were no project milestones/goals included in the documentation in the project file.

\section{Service Description}

The service will provide two morning express bus trips and two evening express bus trips to/from Net Park through downtown Tampa to Oldsmar.

\section{Progress}

This is a new project. There have been no progress reports submitted to date.

\section{Pinellas Suncoast Transit Authority (PSTA)}

The Pinellas Suncoast Transit Authority (PSTA) is an independent authority created by a special act of the Florida Legislature, and is governed by a Board of Directors comprised of one appointee from Pinellas County and one from the City of St. Petersburg, one elected County Commissioner, and 8 elected officials representing the 24 municipalities served by PSTA. PSTA directly operates fixed-route motorbus service and demand-response services, with some of the demand response service purchased from local private providers.

\section{Route 59/Route 73 Service - WPI \#7816678}

\section{Project Scope}

The purpose of this project was to provide continuous fixed route service along the Ulmerton Road/Roosevelt Boulevard/9th Street North corridor from Indian Rocks 
Shopping Center in western Pinellas County to the Gateway Mall in eastern Pinellas County via PSTA Route 59. (Route 59 was initiated in October 1992 with a Service Development grant from the Department). It also includes the extension of Route \#73 from its original terminus at Starkey and Ulmerton Roads to downtown Clearwater in order to provide linkages to major residential areas and employment and other attractors along County Road 1 and northwest Clearwater via other PSTA bus routes.

From October 1992 through December 1994, the FDOT and PSTA jointly funded Route 59 as a Service Development project. Effective November 21, 1995, service was funded by FDOT and PSTA under the FDOT Transit Corridor Program.

\section{Project Milestones/Goals}

Separate goals and objectives have been established for Routes 59 and 73. The following goals and objectives have been established for Route 59:

Goal: Facilitate intra-county transit work trips to/from western Pinellas County to/from the Gateway area of Pinellas County via Ulmerton Road and Roosevelt Boulevard.

Objective: Provide service along the Ulmerton Road/Roosevelt Boulevard Corridor linking Indian Rocks Shopping Center on the west with Gateway Mall on the east.

Objective: Provide at a minimum, 30 minute peak-period service frequency and 60 minute service frequency during off-peak periods.

Objective: Maintain schedule transfers when possible at off-street transfer locations including Indian Rocks Shopping Center, Largo Mall, and Gateway Mall.

Goal: $\quad$ Increase the level of ridership by continually monitoring service performance and comparing performance with established performance standards.

Objective: Total ridership of 130,000 one-way passenger trips in FY 1995-96. Once this goal is reached, a 5 percent ridership increase in FY 1996-97. 
Objective: Compare passenger productivity with the system average for passengers per revenue hour and mile. Maintain 11.2 passengers per revenue hour in FY 1995-96 and 11.76 passengers per revenue hour in 1996-97.

Goal: $\quad$ Minimize operating deficits and maximize fare revenue.

Objective: Farebox recovery ratio shall be at a minimum 20 percent.

Objective: Review average fare quarterly and institute system-wide fare increases as necessary, to keep pace with increased operating costs.

Project Goals/Objectives Route 73

The following goals and objectives were established for Route 73:

Goal: Facilitate intra-county transit trips to/from southern Pinellas County to/from the downtown area of Clearwater, via Starkey/Keene road and Gulf-to-Bay Boulevard/Court Street.

Objective: Provide transit service along the Keene/Starkey Road and Gulf-to-Bay Boulevard/Court Street corridors linking Tyrone Square Mall in St. Petersburg with the Park Street Terminal in downtown Clearwater.

Objective: Provide, at a minimum, 60 minute service frequency during weekday periods.

Objective: Maintain scheduled transfers when possible at off-street transfer locations including Tyrone Square Mall and Park Street Terminal.

Goal: Increase the level of ridership by continually monitoring service performance and comparing performance with the established performance standards.

Objective: Total additional ridership of 213,192 one-way passenger trips over the course of the three-year demonstration period. Approximately 40,000 additional passenger trips in FY 1997/98. 
Objective: Compare passenger productivity with the system average for passengers per revenue hour and mile. Achieve 10.3 passengers per revenue hour in FY 1998-99 and 10.8 passengers per revenue hour in 1999/00.

Goal: $\quad$ Minimize operating deficits and maximize fare revenue.

Objective: Farebox recovery ratio shall be at a minimum 20 percent at the conclusion of the three-year demonstration period.

Objective: Review average fare quarterly and institute system-wide fare increases as necessary, to keep pace with increased operating costs.

Service Description - Route 59

Route 59 provides service along the Ulmerton Road/Roosevelt Boulevard Corridor linking Indian Rocks Shopping Center on the west with Gateway Mall on the east. Service is provided at a 30 minute peak-period frequency and a 60 minute service frequency during off-peak periods.

Service Description - Route 73

Route 73 provides transit service along the Keene/Starkey Road and Gulf-to-Bay Boulevard/Court Street corridors linking Tyrone Square Mall in St. Petersburg with the Park Street Terminal in downtown Clearwater. Service is provided at a 60 minute frequency during weekday periods.

Progress - Route 59

In meeting the first goal established for Route 59, the route currently provides continuous fixed route service along the Ulmerton Road/Roosevelt Boulevard/9th Street North corridor from Indian Rocks Shopping Center in western Pinellas County to Gateway Mall in eastern Pinellas County. In addition, the provision of frequent peak period service (30 minute service frequency) on Route 59 helps facilitate cross-county movements through feeder service to/from other line haul routes, such as Routes 18 , 
19, and 52. Route 59 also provides for a maximum number of transfer opportunities from minor connectors in the PSTA system.

Ridership has shown steady increases since the implementation of the service in October 1992. During FY 1996, weekday ridership on Route 59 totaled 144,771 oneway passenger trips, which is an increase of 11.21 percent over the prior fiscal year. In FY 1997, ridership increased an additional 14.7 percent with 165,992 one-way passenger trips. In FY 1998, ridership increased 25.31 percent to 208,003 one-way passenger trips.

Passenger productivity (passengers per revenue hour) was 12.37 in FY 1996 and was 14.18 in FY 1997, exceeding the goal of 11.76 for the entire year. While this was short of the system average of 20 passengers per revenue hour, productivity in more recent fiscal years are closer to the overall system average. During the first nine months of FY 1999, passengers per revenue hour increased to 19.11 percent.

Growth in average daily ridership on Route 59 has reduced the operating deficit and as a result, improved the farebox recovery ratio. In FY 1996, the operating ratio was 20.53 percent. Through the first six months of FY 1999, the operating ratio was 29.36 percent.

Progress - Route 73

PSTA has met the first goals established for Route 73 . The route currently provides continuous fixed route service along Park Street/Starkey/Keene Road and Gulf-to-Bay Boulevard/Court Street corridors from Tyrone Square Mall in western St. Petersburg to Park Street Terminal in downtown Clearwater. Service frequency is 60 minutes during weekdays and on Saturday.

Ridership growth has occurred on Route 73 as a result of the extension of service form the mid-county area to downtown Clearwater. An additional 3,457 one-way passenger trips were recorded during the first two months of operation. Ridership growth in FY 1998 resulted in an additional 31,348 one-way passenger trips for the entire fiscal year. Passenger productivity for the first two quarters of 1999 was 12.35 passengers per revenue hour. 
In the most recent status report available, it was stated that continued ridership growth on Route 73 will be needed to offset the operating deficit and improve the operating ratio (at that time, 19.97 percent).

\section{Route 100X - WPI \# 7816679}

\section{Project Scope}

The Route 100X was originally implemented in August 1985 by HART as a commuter express route providing inter-county service between Hillsborough and Pinellas Counties in an effort to help relieve congestion and improve capacity on east-west Pinellas to Hillsborough connectors. In October 1990, the operation of Route 100X was transferred from HART to PSTA.

The original Joint Participation Agreement between FDOT and PSTA was for $\$ 124,949$, providing operating, administrative, management and marketing support for the project. Subsequent supplemental agreements provided an additional $\$ 1,024,316$ to the project.

\section{Project Milestones/Goals}

Goal 1: Facilitate inter-county transit work trips to/from the Gateway area of Pinellas County to/from downtown Tampa, via the Gandy Bridge and the Crosstown Expressway.

Objective: Utilize Gateway Mall as an intermodal transfer point for cross-bay commuter express service via Route 100X.

Objective: Provide commuter bus service during periods of peak congestion with limited stops with premium fares and multi-ride tickets, and coordinate the Route 100X schedule for the convenience of work trip commuters and major employers in both downtown Tampa and the Gateway area in Pinellas County.

Objective: Establish Route 100X as an alternative to the automobile for work trips, thereby reducing traffic congestion. 
Goal 2: Increase the level of ridership and customer satisfaction by continually monitoring service performance and comparing performance with established performance standards.

Objective: Achieve annual ridership level of 50,000 passengers in Fiscal Year 1995/96. Beginning in FY 1996/97 strive for ridership increases of $2 \%$ annually.

Objective: Utilize focus groups and continue conducting periodic on-board surveys to ascertain customer satisfaction and identify potential service improvements.

Goal 3: $\quad$ Minimize operating deficits and maximize fare revenue.

Objective: Farebox recovery ratio shall be a minimum of $20 \%$.

Objective: Average vehicle load of 10 passengers for each scheduled bus trip.

Objective: Review average fare quarterly and institute fare increases as necessary to keep pace with increased operating costs.

\section{Service Description}

Route 100X remains a commuter route providing service from the Gateway Mall lot in St. Petersburg to the Marion Street Transit Parkway in Tampa, via $4^{\text {th }}$ Street North, the Gandy Bridge, Gandy Boulevard, Dale Mabry Highway, and the Crosstown Expressway.

\section{Progress}

Consistent with the first goals established for the route, Route 100X provides round-trip commuter service from Gateway Mall to the Marion Street Transit Plaza in Tampa with 30 minute service frequency during a.m. and p.m. peak periods, Monday through Friday. Gateway Mall serves as the transfer point for the Route 100X, PSTA Routes 1, $4,9,11,16,59$, and 74 . HART also has local feeder routes providing frequent and direct access to Route 100X. 
As part of a public-private partnership, PSTA has worked very closely with the management of the Gateway Mall to replace existing shelters and provide accessible paths of travel to/from those shelters in accordance with the Americans with Disabilities Act requirements. Unfortunately, the improvements at the mall resulted in the elimination of park-n-ride spaces used by $100 \mathrm{X}$ patrons. A replacement lot was established at Derby Lane on Gandy Boulevard, effective April 1998.

Ridership totaled 49,621 one-way passenger trips in Fiscal Year 1994/1995. While this was short of the annual ridership objective, there have been subsequent and continued improvement. Total ridership increased again in FY 1995/96 to 50,726 one-way passenger trips, achieving their ridership objective. In FY 1996/97, ridership increased 11.65 percent to 56,636 one-way passenger trips. In FY 1997/98 ridership increased an additional 2.17 percent.

In October 1995, PSTA implemented service improvements which combined PSTA routes 4 and 24 to provide frequent and continuous service along the $4^{\text {th }}$ Street corridor from the Pinellas Point area to $116^{\text {th }}$ Avenue north. This allowed passengers residing along $4^{\text {th }}$ Street south to travel to/from the Gateway Mall without having to transfer, thereby providing a direct connection to Route 100X.

In 1998, a market research project was conducted using focus groups and an on-board survey instrument. One of the major conclusions of the report is that PSTA is growing as a transportation option for workers. At the time the study was conducted, 76 percent of PSTA riders were using the bus to get to work, versus 53 percent in 1995.

Average vehicle load is currently less than 10 passengers. As a result, PSTA will continue to monitor those trips that fall below the norm. However, the operating ratio for this period was significantly greater than the minimum goal of 20 percent, 27.03 percent. The average fare collected was $\$ 1.45$.

\section{Alternate US 19 and SR 686 Corridors - Route \#98 Express Service - FPN \# 40390118401}

Project Scope

Express Route \#98 was designed to provide intra-county transit work trips to/from the Clearwater and Largo areas of Pinellas County to/from Carillon Business Park in an 
effort to alleviate congestion along the Alternate US 19 and SR 686 corridors, following PSTA Route \#52.

Immediately prior to the initiation of Route \#98, the Carillon Business Park experienced a tremendous amount of employment growth. The new employers within the office park requested additional transit service for their employee commutes. A zip code analysis revealed that those employers had a significant number of employees who resided along the Alternate U.S. 19 and SR 686 corridors, justifying the need for the additional service within the corridor.

The joint participation agreement between the FDOT and PSTA provided $\$ 98,064$ for the operation of the project. A supplemental JPA was signed in September 1999 providing an additional $\$ 127,648$ to the project for a total approved budget of $\$ 225,712$. The project is $100 \%$ state funded.

\section{Project Milestones/Goals}

Goal 1: Facilitate intra-county transit work trips to/from the Clearwater and Largo areas of Pinellas County to/from Carillon Business Park, via the Alternate US 19 and SR 686 corridors effective October 1998.

Objective: Provide 30 minute service frequency during morning and afternoon peak periods.

Objective: Provide commuter bus service in only one direction during periods of peak congestion with limited stops, connecting downtown Clearwater with Carillon Business park along the Alternate US 19 and SR 686 corridor.

Goal 2: Increase the level of ridership and customer satisfaction by continually monitoring service performance and comparing performance with established performance standards.

Objective: Annual ridership of 16,000 passengers in FY 1998/1999, with a $10 \%$ ridership increase in FY 1999/2000.

Objective: Compare passenger productivity with the system average per passengers per revenue hour and mile for PSTA commuter routes. 
Goal 3: $\quad$ Minimize operating deficits and maximize fare revenue.

Objective: Farebox recovery ratio shall be at a minimum of $10 \%$.

Objective: Review average fare quarterly and institute fare increases as necessary, to keep pace with increased operating costs.

\section{Service Description}

Route \#98 operates from 5:45 a.m. to 7:40 a.m. and from 4:05 p.m. to 6:05 p.m., Monday through Friday with 30 minute service frequency. Three trips are provided during the a.m. peak period and three are provided in the p.m. peak period to/from the Clearwater and Largo areas of Pinellas County to/from Carillon Business Park via Alternate US 19 and the SR 686 corridors.

\section{Progress}

The most recent progress report for this project is for the $1^{\text {st }}$ quarter of FY 2000. Based on information contained in this report, PSTA met the first goal for the project and the corresponding objectives. Route 98 provides peak commuter bus service along the SR 686 and US 19 corridors connecting downtown Clearwater with the Carillon Business Park. Service is provided Monday through Friday with 30 minute service frequency.

The second goal and corresponding objectives were met over the past year and through the first quarter of $F Y 2000$. FY 1999 ridership was 21,251 persons well above the goal of 16,000 passengers. Ridership during the reporting period was 6,912 passengers. Annual ridership for FY 2000 is expected to increase significantly over the next year at a rate in excess of the 10 percent established as the objective. PSTA also exceeded the objective of $10 \%$ farebox recovery, reporting a recovery ratio of 13.4 percent for the quarter. They also maintained a level of average fare at $\$ 0.77$ per trip that was greater than the current system average of $\$ 0.753$.

The Action Plan provided in the progress report suggested that PSTA improve passenger amenities along the route and promote increased participation in Medicaid, Transportation Disadvantaged, and the WAGES bus pass programs and continue the performance monitoring and passenger productivity monitoring of the route. 


\section{Ulmerton Road (SR 688) Corridor - Route \#99 Express Service - FPN \# 40390318401}

Project Scope

Express Route \#99 was designed to provide intra-county transit work trips to/from western Pinellas County to/from Carillon Business Park in an effort to alleviate congestion along the Alternate US 19 and SR 686 corridors.

During the months immediately preceeding the establishment of Route \#99, the Carillon Business Park experienced a tremendous amount of employment growth. The new employers within the office park requested additional transit service for their employee commutes. A zip code analysis revealed that those employers had a significant number of employees who resided along the Ulmerton Road corridor from the Walsingham area in western Pinellas County east to US 19. Using the results of the zip code analysis as justification, PSTA proposed this new express route that would provide service from the Indian Rocks Shopping Center to Carillon Business Park via Ulmerton Road (SR 688).

\section{Project Milestones/Goals}

Goal 1: Facilitate intra-county transit work trips to/from western Pinellas County to/from the Carillon area of Pinellas County, via Ulmerton Road effective October 1998.

Objective: Provide commuter service in only one direction during periods of peak congestion with limited stops, connecting outlying suburbs with Carillon Business Park along the Ulmerton Road (SR 688) corridor.

Objective: Provide 30 minute service frequency during morning and afternoon peak periods.

Goal 2: Increase the level of ridership by continually monitoring service performance and comparing performance with established performance standards.

Objective: Compare passenger productivity with the system average for passengers per revenue hour and mile for PSTA commuter routes. 
Goal 3: $\quad$ Minimize operating deficits and maximize fare revenue.

Objective: Farebox recovery ratio shall be at a minimum $10 \%$.

Objective: Review average fares quarterly and institute system-wide fare increases as necessary to keep pace with increased operating costs.

\section{Service Description}

Route 99 provides commuter service in only one direction during periods of peak congestion with limited stops, connecting outlying suburbs with Carillon Business Park along the Ulmerton Road (SR 688) corridor. Service is provided with 30 minute frequency during morning and afternoon peak periods.

\section{Progress}

The most recent progress report for this project is for the $3^{\text {rd }}$ quarter of FY 1999. Based on information contained in this report, PSTA met the first goal for the project and the corresponding objectives. Route 99 provides peak commuter bus service along the SR 688 corridor connecting suburban areas in western Pinellas County with the Carillon Business Park. Service is provided Monday through Friday with 30 minute service frequency.

The second goal and corresponding objective was not met during this period. Ridership during the period was 3,221 passengers. It was suggested that the target ridership of 14,000 one-way passenger trips for the fiscal year was too high based on the current level. PSTA did not meet the objective of $10 \%$ farebox recovery, reporting a recovery ratio of 7.5 percent. However, they did maintain a level of average fare at $\$ 0.82$ per trip that was greater than the system average of $\$ 0.725$.

The Action Plan provided in the progress report suggested that PSTA improve passenger amenities along the route and promote increased participation in Medicaid, Transportation Disadvantaged, and the WAGES bus pass programs. Additional activities included extending service to Scherer Drive and $34^{\text {th }}$ Street to generate 
additional ridership in the mid-county industrial area; continue the performance monitoring and passenger productivity monitoring of Route 99.

\section{US 19 Corridor Service Marketing - FPN \# 406476100507}

Project Scope

To market new U.S. 19 intercounty bus route services.

Project Milestones/Goals

The goal established for the project is the implementation of the following marketing program elements that were adopted for this project.

\section{Advertising Elements:}

- Pasco Utility Bills - promotional flyers will be inserted into all West Pasco County utility bills. The flyer will introduce the service and have a map and schedule.

- Radio - WGUL - AM/FM, the Gull, dual broadcast station that caters to the senior audience. Spots will be produced by the WGUL at not cost.

- Suncoast News - This neighborhood newspaper reaches all areas of Pasco County and is printed on Tuesdays and Saturdays. Inserts will be provided targeting the U.S. 19 corridor.

- The St. Petersburg Times - Several cost effective programs are recommended with the St. Petersburg Times to reach the target audience: advertisements should be run in the Pasco and North Pinellas Neighborhood Times sections. The insert flyer will be placed in the vendor machine papers in Pasco County to reach more transient populations. In addition, an advertisement will be developed and placed in the monthly Seniority Publication that has a circulation of 50,000.

\section{Public Relations Elements:}


- Ribbon Cutting/Pre-Opening Day Event - local politicians and the press will be invited to ride the route the day before the service begins. This pre-promotion will provide an opportunity to capture the press for entry into the next day's news.

- Press Releases - Pre- and post-start press releases should be written and issued to the local media.

- County Access TV - Coordinate with Government Access channels in Pinellas and Pasco Counties to air feature stories.

- Pasco County Website - Create an information page about the new Pasco - Pinellas U.S. 19 Route highlighting details such as schedules and other route connections.

- Pre-promotion Event at Gulfview Square Mall - Make arrangements with the mall to set up a display booth to introduce the bus service prior to implementation.

Distribute materials and tell people the basics of how to ride.

- Employer/Business Outreach - Develop a mailing list of local employers, employment agencies and temporary services. Communicate the availability of service for their employees and clients. Make supplies of schedules available to them. Attend local job fairs and employment oriented programs. Additionally, since this route serves the commercial corridor of U.S. 19, there may be some opportunities for cross-promotional advertisements with local businesses. Retail establishments should be contacted as the marketing materials are developed to solicit their support and cooperation.

- Outreach to St. Petersburg Junior College and Pasco-Hernando Community College (PHCC) - Request their assistance through the use of articles in the campus newspapers and admissions materials. Highlight the Bikes on Buses program for St. Petersburg Junior College.

- Churches and Community Organizations and Chambers of Commerce, Mobile Home Parks and Senior Housing - Conduct mailings and presentations to local community organizations such as seniors, etc. who can help market the new service to their members. Ask various locations to post the bus schedule. Additionally, contact should be made with local scout troops to ask for their assistance in distributing schedules. 
- PSTA "On Board News" - Include information in the Fall or Winter issue of this publication.

- On-Board Announcements - Display special posters behind the drivers of all PSTA routes in and out of Countryside Mall.

- Employee Communication - Information should be included in employee newsletters such as PSTA's FOCUS on Communications.

Service Description

Not Applicable

Progress

There have been no progress reports submitted to date.

\section{Cross-County Service (CR 296) Corridor - Route \#58 - FPN \# 40647718401}

Project Scope

The CR 296 corridor is a major arterial roadway in Mid-Pinellas County, which links residential areas in western Pinellas County with commercial and industrial employment in eastern Pinellas County. This east-west corridor is located between Ulmerton Road (SR 688) and Park Boulevard (SR 694) and is designed to relieve congestion on both of these major urban corridors. Currently, PSTA has very productive cross-county transit service on both Ulmerton Road and Park Boulevard but not service on CR 296.

Implementation of public transit service along CR 296 will serve to facilitate transit strips to/from western Pinellas County and the ICOT Center Business Park including service to the new St. Petersburg Junior College Campus in Seminole. Moreover, the route will provide the opportunity for transfers to/from routes serving the Seminole Mall (Routes 18 and 74) and the Bay Area Outlet Mall (Routes 19,51,79, and 98).

\section{Project Milestones/Goals}

The following objectives and criteria for success have been established for the project. 
Project Objectives: Funding for the initiation of service from the Seminole Mall to the Bay Area Outlet Mall and establishment of CR 296 as a primary east-west transit corridor.

Criteria for Success: Total ridership of 250,000 passengers during the course of the three year demonstration project.

Service Description

Route 58 operates from 5:30 a.m. tp 7:30 p.m. Monday through Friday, with 30 minute service frequency during peak periods and 60 minute service frequency during off-peak. The service alignment provides opportunities for off-street transfers at Seminole Mall and the Bay Area Outlet Mall, thereby increasing access to numerous routes systemwide. Transfer activity is also available to routes serving Seminole Boulevard, Starkey Road, Belcher Road, $66^{\text {th }}$ Street and Ulmerton Road, thereby increasing ridership on Routes $18,59,62,73$, and 79 . This further facilitates intra-county movements, particularly for commuters.

\section{Progress}

This is a new project. There have been no progress reports submitted to date.

\section{Fixed Route Service from Tarpon Mall to Oldsmar (SR 584 Corridor) - FPN \# 40647818401}

Project Scope

Funding has been provided for the initiation of fixed route transit service from the Tarpon Mall to the Tri-County Business/Industrial Park in Oldsmar, lending to the establishment of Tampa Road (SR 584) as a primary east-west transit corridor.

\section{Project Milestones/Goals}

There were no project milestones/goals included in the documentation in the project file.

Service Description 
This project will enable the agency to provide fixed route transit service from the Tarpon Mall to the Tri-County Business/Industrial Park in Oldsmar.

\section{Progress}

This is a new project. There have been no progress reports submitted to date.

\section{Pasco County Public Transportation}

\section{US 19 Corridor Project - FPN \# 40648118401}

\section{Project Scope}

To provide fixed route bus service along the U.S. 19 corridor through a joint effort with the Pinellas Suncoast Transit Authority.

\section{Project Milestones/Goals}

There were no project milestones/goals included in the documentation in the project file.

\section{Service Description}

Fixed route bus service along the U.S. 41 corridor between Pasco and Pinellas Counties.

\section{Progress}

This is a new project. There have been no progress reports submitted to date.

\section{NEXT STEP}

The next step in the process of reviewing the FDOT Transit Corridor Program is to develop a "lessons learned" document that provides insight into the relative success and/or failure of each of the corridor projects identified in this technical memorandum in meeting the goals, milestones that were established. In order to adequately evaluate the projects' effectiveness in meeting the goals established, the next effort will include interviews and/or discussions with FDOT district and central office staff members and 
staff from Florida's transit agencies. This effort will result in a second technical memorandum.

During the interviews discussed above, investigators will also be reviewing the overall effectiveness of the Transit Corridor Program in meeting the statewide program goals of relieving congestion and improving the capacity along and within constrained travel corridors. FDOT district and central office staff will also be asked to share any strengths or weaknesses they see in the program in the areas of program management and implementation, including the project selection process, eligible activities, funding issues, and monitoring. If there are areas identified as problematic, by those interviewed, recommendations will be made to the Department to aid in the continual improvement of the Transit Corridor Program. The results of the interviews and any recommendations that develop as a result of the interviews will be contained in a third technical memorandum. 